\title{
The Cephennium fauna of Turkey and the Middle East (Coleoptera: Staphylinidae: Scydmaeninae)
}

\author{
With 71 figures and 3 maps
}

Volker Assing ${ }^{1}$ and Heinrich MeybOhm ${ }^{2}$

${ }^{1}$ Gabelsbergerstraße 2, 30163 Hannover, Germany. - vassing.hann@t-online.de
${ }^{2}$ Wassenkamp 2a, 22927 Großhansdorf, Germany. - hmeybohm@t-online.de
Published on 2021-06-30
DOI: 10.21248/contrib.entomol.71.1.001-028

\begin{abstract}
Only two species of Cephennium Müller \& Kunze, 1822 were previously known from Turkey and the Middle East including Lebanon, Israel, Jordan, Iraq, and Iran. An examination of material collected during numerous field trips to Turkey and Jordan in the past four decades revealed that the Cephennium fauna of Turkey is remarkably diverse. In total, 25 named species are recognized, diagnosed, illustrated, and assigned to four species groups. Based on zoogeographic, morphological, and additional evidence, C. bodemeyeri REITTER, 1903, previously a subspecies of C. perispinctum Kolenati, 1846, is elevated to species rank. Twenty-three species are described for the first time: Cephennium fractum spec. nov. (Turkey: Bursa, Balıkesir, Kocaeli, Çanakkale), C. infractum spec. nov. (Turkey: Bursa), and C. immutatum spec. nov. (Turkey: Izmir, Muğla, Adıyaman) of the C. perispinctum group; C. ericinum spec. nov. (Turkey: Ordu), C. varispinosum spec. nov. (Turkey: Ordu), C. victrix spec. nov. (Turkey: Sinop), C. spinigerum spec. nov. (Turkey: Bartin), and C. digitale spec. nov. (Turkey: Zonguldak) of the C. ericinum group; C. reductum spec. nov. (Turkey: Konya, Antalya, Mersin, Kastamonu) of the C. jonicum group; C. corruptum spec. nov. (Turkey: Mersin, Adana), C. marasicum spec. nov. (Turkey: Kahramanmaraş), C. dolucanum spec. nov. (Turkey: Kahramanmaraş), C. fimbriatum spec. nov. (Turkey: Adana), C. besucheti spec. nov. (Turkey: Kahramanmaraş), C. affimbriatum spec. nov. (Turkey: Kahramanmaraş), C. kartalicum spec. nov. (Turkey: Gaziantep), Cephennium nemruticum spec. nov. (Turkey: Adıyaman), C. unguicum spec. nov. (Turkey: Aydın), C. deplectens spec. nov. (Turkey: Izmir, Manisa), C. sicaferum spec. nov. (Turkey: Aydın), C. geminum spec. nov. (Turkey: Antalya), C. duplum spec. nov. (Turkey: Muğla), and C. jordanicum spec. nov. (Northwest Jordan) of the C. corruptum group. Several additional species, all of them represented exclusively by females and most likely belonging to the C. corruptum group, remain undescribed. A key to the named species of Turkey and the Middle East is provided. The distributions of the species recorded from Turkey are mapped. In an appendix, C. liguliferum spec. nov. (Southeast Bulgaria), a close relative of C. bodemeyeri and C. perispinctum, is described and illustrated.
\end{abstract}

\section{Taxonomic acts}

Cephennium fractum spec. nov. - urn:lsid:zoobank.org:act:26CE8301-2927-4893-B93E-9F2BEF4F7F07

Cephennium infractum spec. nov. - urn:lsid:zoobank.org:act:E222C4A2-D6AC-48FF-AC4C-B274EF405209

Cephennium immutatum spec. nov. - urn:lsid:zoobank.org:act:F24C0315-7B6F-427E-B9AB-65AB304F7718

Cephennium ericinum spec. nov. - urn:lsid:zoobank.org:act:F56474A9-C330-4019-BD58-B566E66CF58E

Cephennium varispinosum spec. nov. - urn:lsid:zoobank.org:act:04C4304D-F84A-400B-8710-15407DE9BCCD 
Cephennium victrix spec. nov. - urn:lsid:zoobank.org:act:2BC2443C-70A2-4B5B-874A-FAF0F4DCFB62 Cephennium spinigerum spec. nov. - urn:lsid:zoobank.org:act:7321FC90-18ED-4F50-8CFA-58F338EA62BB Cephennium digitale spec. nov. - urn:lsid:zoobank.org:act:06ED0DE9-D72E-410C-9A7A-B7330175D3D9 Cephennium reductum spec. nov. - urn:lsid:zoobank.org:act:CB292C96-5EC1-4947-AE0F-3D3F3094C77A Cephennium corruptum spec. nov. - urn:lsid:zoobank.org:act:BC5C6DE3-2696-4949-B84F-E7336C5DC774 Cephennium marasicum spec. nov. - urn:lsid:zoobank.org:act:02420408-99DB-49FA-8A5B-409528E5613A Cephennium dolucanum spec. nov. - urn:lsid:zoobank.org:act:F0BFE9A7-0AE9-40D2-BC5E-49DE875B2A65 Cephennium fimbriatum spec. nov. - urn:lsid:zoobank.org:act:831C051F-751A-4D9C-A9DA-7E2BCAA4D82E Cephennium besucheti spec. nov. - urn:lsid:zoobank.org:act:831C051F-751A-4D9C-A9DA-7E2BCAA4D82E Cephennium affimbriatum spec. nov. - urn:lsid:zoobank.org:act:02ED0B80-53CF-4ED8-8648-F45DC12696B5 Cephennium kartalicum spec. nov. - urn:lsid:zoobank.org:act:27B66398-BD3C-4C54-9DF8-0918EEEB6C65 Cephennium nemruticum spec. nov. - urn:lsid:zoobank.org:act:643B8783-90BC-4DE2-9DA7-45EFCF67778C Cephennium unguicum spec. nov. - urn:lsid:zoobank.org:act:92FD91A3-6A6F-4EBB-BBBF-2CA222D6FD14 Cephennium deplectens spec. nov. - urn:lsid:zoobank.org:act:E16431E9-E6B9-411F-B164-3FA1B7A4D2E2 Cephennium sicaferum spec. nov. - urn:lsid:zoobank.org:act:7F1029CB-AD9C-42A6-BBAC-5BDC653EBFEC Cephennium geminum spec. nov. - urn:lsid:zoobank.org:act:36759AD0-8CA5-44E3-A0A0-D50329D09B0C Cephennium duplum spec. nov. - urn:lsid:zoobank.org:act:B2B65A3E-757E-44EB-9F6F-C46D7523A3EB Cephennium jordanicum spec. nov. - urn:lsid:zoobank.org:act:900BF391-A399-4559-A132-F1E8F1CFB3E7 Cephennium liguliferum spec. nov. - urn:lsid:zoobank.org:act:BE39D1DA-3677-435F-A8EB-D34BE361F9F5

\section{Key words}

Coleoptera, Staphylinidae, Scydmaeninae, Cephennium, taxonomy, new species, species groups, West Palaearctic, Middle East, Turkey, Jordan, Bulgaria, endemism, distribution maps

\section{Zusammenfassung}

Lediglich zwei Arten der Gattung Cephennium Müller \& Kunze, 1822 waren bislang aus der Türkei und dem Nahen Osten (Libanon, Israel, Jordanien, Irak, Iran) bekannt. Die Bearbeitung von Material, das auf zahlreichen Forschungsreisen in die Türkei und nach Jordanien in den vergangenen vier Jahrzehnten gesammelt wurde, ergab, dass die Cephennium-Fauna insbesondere der Türkei bemerkenswert divers ist. Insgesamt 25 benannte Arten werden unterschieden, abgebildet und vier Artengruppen zugeordnet. Zoogeographische, morphologische und weitere Argumente legen nahe, dass C. bodemeyeri ReItTer, 1903, bisher Unterart von C. perispinctum Kolenati, 1846, als distinkte Art zu betrachten ist. Dreiundzwanzig Arten werden erstmals beschrieben: Cephennium fractum spec. nov. (Türkei: Bursa, Balıkesir, Kocaeli, Çanakkale), C. infractum spec. nov. (Türkei: Bursa) und C. immutatum spec. nov. (Türkei: Izmir, Muğla, Adıyaman) aus der C. perispinctum-Gruppe; C. ericinum spec. nov. (Türkei: Ordu), C. varispinosum spec. nov. (Türkei: Ordu), C. victrix spec. nov. (Türkei: Sinop), C. spinigerum spec. nov. (Türkei: Bartin) und C. digitale spec. nov. (Türkei: Zonguldak) aus der C. ericinum-Gruppe; C. reductum spec. nov. (Türkei: Konya, Antalya, Mersin, Kastamonu) aus der C. jonicum-Gruppe; C. corruptum spec. nov. (Türkei: Mersin, Adana), C. marasicum spec. nov. (Türkei: Kahramanmaraş), C. dolucanum spec. nov. (Türkei: Kahramanmaraş), C. fimbriatum spec. nov. (Türkei: Adana), C. besucheti spec. nov. (Türkei: Kahramanmaraş), C. affimbriatum spec. nov. (Türkei: Kahramanmaraş), C. kartalicum spec. nov. (Türkei: Gaziantep), Cephennium nemruticum spec. nov. (Türkei: Adıyaman), C. unguicum spec. nov. (Türkei: Aydın), C. deplectens spec. nov. (Türkei: Izmir, Manisa), C. sicaferum spec. nov. (Türkei: Aydın), C. geminum spec. nov. (Türkei: Antalya), C. duplum spec. nov. (Türkei: Muğla), and C. jordanicum spec. nov. (Nordwest-Jordanien) aus der C. corruptum-Gruppe. Einige weitere, ausschließlich durch Weibchen vertretene und wahrscheinlich zur C. corruptum-Gruppe gehörende Arten bleiben unbenannt. Für die beschriebenen Cephennium-Arten der Türkei und des Nahen Ostens wird eine Bestimmungstabelle erstellt. Die Verbreitungsgebiete der aus der Türkei nachgewiesenen Arten werden anhand von Karten illustriert. In einem Anhang wird C. liguliferum spec. nov. (Südost-Bulgarien), eine mit C. bodemeyeri and C. perispinctum nah verwandte Art, beschrieben und abgebildet.

\section{Schlüsselwörter}

Coleoptera, Staphylinidae, Scydmaeninae, Cephennium, Taxonomie, neue Arten, Artengruppen, Westpaläarktis, Naher Osten, Türkei, Jordanien, Bulgarien, Endemismus, Verbreitungskarten 


\section{Introduction}

According to JaŁoszyŃski \& STEVANOvić (2015) and the latest edition of the Palaearctic Catalogue (SCHÜLKe \& Smetana 2015), the speciose genus Cephennium MÜller \& KunZe, 1822 is distributed in the West Palaearctic region eastwards to Middle Asia and included nearly 150 species and several subspecies assigned to six subgenera. In recent years, 55 species have been added: 39 new species and one revalidation from France (Orousset 2017a, b, 2018, 2019), twelve new species from the Greek island Crete (Assing 2019), one from the Greek island Karpathos (Меүвонм 2016), one from Spain (JAŁOSZYŃSKi \& STRUyve 2016), and one from Kyrgyzstan (JaŁoszyński \& Stevanović 2015). With few exceptions, the recently described species are anophthalmous or microphthalmous. According to JAŁOSZYŃski \& STEvANOvić (2015), who also illustrate the general distribution of the genus known at that time, the current subgeneric concept is problematic and largely artificial.

Cephennium species are generally inhabitants of the litter layer and of deeper soil strata. The latter particularly applies to microphthalmous and anophthalmous species currently assigned to the subgenus Geodytes SAULCY, 1864, to Phennecium Normand, 1912, or listed as incertae sedis, and which are usually locally endemic. In Crete, these species have been collected primarily or exclusively by soil-washing (Assing 2019).

Prior to the present study, only a single Cephennium species, C. (Cephennium) perispinctum bodemeyeri ReITTER, 1903, had been reported from Turkey, and C. (Phennecium) judaeum ReITter, 1882 from Lebanon was the sole representative of the genus in the Middle East region comprising Lebanon, Israel, Jordan, Iran, and Iraq (Schülke \& Smetana 2015). During the past four decades, numerous field trips to Turkey have been conducted by the second author and Volker Brachat (Geretsried), as well by the first author, partly together with Michael Schülke (Berlin) or Paul Wunderle (Mönchengladbach). These field trips covered various regions, particularly North Turkey eastwards to Rize, West and Southwest Turkey, and South Turkey eastwards to Adiyaman. Several additional field trips, among them one to Jordan, were conducted to the Middle East by the second author. These field trips yielded a substantial number of Cephennium specimens belonging to more than 20 species, all of them undescribed, except for C. perispinctum bodemeyeri.

The conditions for entomological field work in Turkey have become rather unfavourable (to put it mildly) in recent years, at least for non-Turkish nationals. Since, as a consequence, future field trips to this entomologically interesting region now seem unlikely, we believe that this is a good time to present the results of our previous field work.

\section{Material and methods}

The material treated or mentioned in this study is deposited in the following collections:

HNHM Hungarian Natural History Museum, Budapest MNB Museum für Naturkunde Berlin (coll. Schülke)

NHMW Naturhistorisches Museum Wien

cAss private collection V. Assing, Hannover

The morphological studies were conducted using Stemi SV 11 (Zeiss) and Discovery V12 (Zeiss) microscopes, and a Jenalab compound microscope (Carl Zeiss Jena). The images were created using digital cameras (Axiocam ERc 5s, Nikon Coolpix 995), as well as Labscope and Picolay software. The maps were created using MapCreator 2.0 (primap) software.

Body length was measured from the anterior margin of the labrum to the apex of the elytra, pronotal length along midline, pronotal width at its maximal extension, and the length of the aedeagus from the apex of the ventral process to the base of the aedeagal capsule. The "parameral" side (i.e., the side where the sperm duct enters) is referred to as the ventral, the opposite side as the dorsal aspect. When assessing the relative length of the paramere, the apical setae are not included.

The labels of type material are cited verbatim; numerous special Turkish characters and diacritic marks are thus given as standard characters.

In the 1960s, the late Claude Besuchet had examined nearly all the available types of Cephennium, accumulated drawings of the aedeagi of numerous described and even more undescribed species, and documented identifications of numerous specimens from various collections. Unfortunately, he never published his results, but both his drawings and his documentation of examined material was recently made available to the authors. In the case of Cephennium bodemeyeri and C. judaeum, the material examined by him, including type material, is listed in the present paper.

\section{Results}

A study of the material collected during numerous field trips conducted to Turkey and Jordan revealed that the Cephennium fauna of Turkey and the Middle East is composed of signifcantly more than twenty species. Including the $23 \mathrm{new}$ species described in this paper, 25 named species are recorded from the region, the vast majority of them (23 species) are regionally or locally endemic in Turkey. Only two species are known from the remainder of the Middle East (Lebanon, Jordan). Several additional, possibly undescribed species, all of them exclusively represented by females, remain unnamed. Moreover, Claude Besuchet (unpublished notes) intended to describe another species of the C. perispinctum group 
based on old material from Belgrad Ormanı (Northwest Turkey: Istanbul province). Since no recently collected material with precise locality data was available, this species remains unnamed for the time being.

In view of the unclarified, weakly supported, and consequently uninformative subgeneric concept currently in use, the species treated in this paper are not attributed to any of the existing subgenera. Instead, they are assigned to four species groups. The C. perispinctum group includes four species, three of them distributed in Northwest Turkey and one in South Turkey. The C. ericinum group is composed of five nearly anophthalmous species, each of them locally endemic in North Turkey in the region from Bartin and Zonguldak in the west to Ordu in the east. The C. jonicum group is represented in the study region by only one species distributed in both the Taurus and the Pontic mountains. The remaining species, the vast majority of them locally endemic, all belong to the C. corruptum group, whose diversity centre is in southern Anatolia, but which also includes two species in Lebanon and Jordan.

\section{Key to the Cephennium species of Turkey and the Middle East}

1. Eyes reduced to minute rudiments without ommatidia (Figs 7-8). Pronotum large in relation to elytra and approximately as broad as elytra (e.g., Figs 6, 9). Elytra without tomentose impressions anteriorly. Species of moderately to relatively large body size; body length $1.3-1.7 \mathrm{~mm}$. Colouration of body reddish to brown. $0^{\star}:$ male protibiae weakly modified at most; aedeagus slender; ventral process more or less gradually tapering apicad and apically acute (Figs 36, 38, 40, 42, 44); internal sac with distinct spines (Figs 37, 39, 41, 43, 45); parameres slender, far from reaching apex of median lobe. Distribution: North Anatolia (Map 2). Cephennium ericinum group.

- Eyes often small, but with (sometimes weakly defined) ommatidia. Pronotum narrower than elytra. Elytra with tomentose impressions anteriorly. Aedeagus of different shape.

2. Largest species of the genus in the study region; body length 1.6-1.8 mm. Body dark-reddish to dark-brown. $0^{*}$ : aedeagus (Fig. 36) 0.44-0.45 mm long; internal structures of distinctive shapes (Fig. 37). Ordu province (Map 2).

ericinum

- Smaller species; body length 1.4-1.5 mm. o $^{*}$ : aedeagus smaller, 0.33-0.39 mm long and with internal structures of different shapes.

3. $0^{\top}$ : aedeagus (Fig. 40) small, approximately $0.33 \mathrm{~mm}$ long; internal structures as in Fig. 41. Sinop (Map 2).

- $\quad o^{\boldsymbol{\lambda}}$ : aedeagus larger, 0.38-0.39 $\mathrm{mm}$ long; internal structures of different shapes and arrangement.

4. $0^{\star}:$ internal structures of aedeagus (Figs 38-39) smaller and less strongly sclerotized. Ordu (Map 2).

varispinosum

- $\sigma^{\star}$ : internal structures of aedeagus more robust and more strongly sclerotized. Species from Northwest Anatolia.

5. $\sigma^{*}$ : internal sac of aedeagus with more numerous spines (Figs 42-43). Bartin (Map 2).

spinigerum

- $\quad \sigma^{\star}$ : internal sac of aedeagus with fewer spines of different shapes (Figs 44-45). Zonguldak (Map 2). digitale

6. Species of larger body size, body length 1.1-1.4 mm. Colouration in mature specimens usually reddish-brown to dark-brown, rarely reddish. Eyes composed of approximately ten, rarely fewer ommatidia. $\sigma^{\top}$ : protibia strongly modified (exception C. immutatum), subapically strongly curved or bent, and excavate on inner side; aedeagus slender, at least $0.38 \mathrm{~mm}$ long; ventral process apically with more or less pronounced median extension; parameres stouter, far from reaching apex of median lobe (apical seta neglected), and with long apical seta. Cephennium perispinctum group.

- Species of small body size; body length $0.9-1.2 \mathrm{~mm}$. Colouration of body reddish-yellow to pale-reddish. Eyes composed of 3-5, often weakly defined ommatidia. $0^{\top}$ : protibia unmodified; aedeagus of compact shape (broad and usually short) and much smaller, approximately $0.33 \mathrm{~mm}$ long at most; apex of ventral process more or less broadly truncate apically; parameres fine and with short apical seta, apically extending (nearly) to or even beyond apex of median lobe.

7. $\sigma^{*}$ : protibia unmodified; aedeagus (Figs 34-35) smaller, approximately $0.38 \mathrm{~mm}$ long, less slender, and with shorter apico-median extension. Southwest and South Turkey (Map 1). immutatum

- $\quad \sigma^{\top}$ : protibia modified, distinctly curved or bent subapically; aedeagus at least approximately $0.5 \mathrm{~mm}$ long, of different shape, and with differently shaped internal structures. Northwest Turkey. 
8. $0^{\text {T: }}$ : aedeagus (Figs 29-31) of more robust shape; parameres basally stouter and distinctly bisinuate. Distributed from Istanbul to Karabük (Map 1).

- $\sigma^{\pi}$ : aedeagus of more slender shape; parameres nearly straight and basally narrow.

9. $\sigma^{\star}$ : aedeagus (Figs 33, 47) shorter, 0.55-0.58 mm long, and with longer apical extension. Bursa (Map 1).

infractum

- $\quad o^{\star}$ : aedeagus (Figs 32, 36) 0.60-0.66 mm long and with shorter apical extension. Bursa, Balıkesir, Kocaeli, Çanakkale (Map 2).

fractum

10. $\sigma^{\top}$ : aedeagus (Figs 48-50) with bulbous base, circular in cross-section basally, approximately twice as long as broad in ventral view; ventral process of the aedeagus apically moderately broadly truncate and in the middle with or without small projection in ventral view; internal structures minute. Cephennium jonicum group. Rather widespread species recorded from both the Taurus and the Pontic Mountains: Konya, Antalya, Mersin, Kastamonu (Map 3).

reductum

- $\quad \sigma^{\top}$ : aedeagus strongly flattened dorso-ventrally, significantly less than twice as long as broad in ventral view; ventral process of aedeagus apically more broadly truncate; internal structures larger in relation to median lobe. Cephennium corruptum group

11. Small species (body length approximately $0.9 \mathrm{~mm}$ ) from the Middle East (Lebanon, Jordan). Eye rudiments minute, with approximately three weakly defined ommatidia.

- Species of often slightly larger average size and distributed in West and South Turkey.

12. $\sigma^{\lambda}$ : apical internal structure of aedeagus more transverse and subapical internal structure more strongly angled (Fig. 67). Jordan. jordanicum

- $\sigma^{\top}$ : apical internal structure of aedeagus less transverse and subapical internal structure less strongly angled (Figs 68-69). Lebanon. judaeum

13. $\sigma^{7}$ : aedeagus with rather large and strongly curved spines in internal sac. West and Southwest Anatolia eastwards to Antalya.

- $\sigma^{\top}$ : aedeagus without claw-shaped internal structures. South Anatolia east of Antalya province.

14. $\sigma^{\text {t }}$ : internal sac of aedeagus with two pairs of claw-shaped spines and with an additional pair of weakly curved spines. Southwest Anatolia: Muğla and Antalya provinces.

- $\sigma^{*}$ : internal sac of aedeagus with one pair of claw-shaped spines, with or without an additional pair of straight spines. West Anatolia.

15. Body length 0.9-1.0 mm. $0^{\star}$ : aedeagus (Figs 65-66) smaller, $0.20 \mathrm{~mm}$ long; internal spines smaller and less strongly curved; apico-median structure less transverse. Muğla (Map 3). duplum

- Body length 1.0-1.1 mm. ơ : aedeagus (Figs 62-64) larger, $0.23 \mathrm{~mm}$ long; internal sac with larger and more strongly curved spines, apico-median structure more transverse. Western Antalya province (Map 3). geminum

16. Body length 1.0-1.1 mm. ơ : aedeagus (Fig. 59) larger, 0.23-0.25 mm long, with a pair of large claw-shaped spines, without additional straight spines. Aydin (Map 3). unguicum

- Body length 0.9-1.0 mm. $\sigma^{-}$: aedeagus smaller, $0.18 \mathrm{~mm}$ long; internal sac with smaller claw-shaped spines and with an additional pair of nearly straight spines.

17. $\sigma^{\star}$ : claw-shaped structures of aedeagus (Fig. 60) strongly curved, apically pointing basad; straight spines very short; apical structure strongly transverse. Izmir, Manisa (Map 3).

deplectens

- $\quad o^{\star}$ : claw-shaped structures of aedeagus (Fig. 61) less strongly curved and apically pointing laterad; straight spines much longer; apical internal structure less transverse. Aydin (Map 3). sicaferum

18. Punctation of pronotum as fine as that of elytra.

- Punctation of pronotum more distinct than that of elytra.

19. $0^{\star}$ : aedeagus (Fig. 57) apically more broadly and more distinctly truncate and with internal structures of distinctive shapes. Mersin, Adana (Map 3). corruptum

- $\quad 0^{\star}$ : aedeagus apically less broadly and less distinctly truncate and with internal structures shaped as in Fig. 55. Kahramanmaraş: environs of Andırın (Map 3). affimbriatum 
20. $0^{\top}$ : internal structures of aedeagus partly fimbriate (Figs 54,58$)$.

- $\sigma^{\top}$ : internal structures of aedeagus not fimbriate.

21. $\sigma^{\top}$ : aedeagus (Fig. 54) approximately $0.32 \mathrm{~mm}$ long, lateral internal structures narrowly fimbriate. Western Kahramanmaraş province (Map 3).

- $\quad \mathrm{o}^{\star}$ : aedeagus (Fig. 58) smaller, $0.27 \mathrm{~mm}$ long, subapical internal structures distinctly fimbriate. Adana (Map 3). .. fimbriatum

22. Species from Kahramanmaraş province.

- Species with more eastern distributions (Gaziantep, Adıyaman).

23. $\sigma^{*}$ : internal structures of aedeagus as in Fig. 52. Distribution: Map 3.

marasicum

- $\sigma^{*}$ : internal structures of aedeagus as in Fig. 53. Distribution: Map 3.

dolucanum

24. $0^{\text {t: }}$ : aedeagus larger, $0.33 \mathrm{~mm}$ long, and with internal structures shaped as in Fig. 51. Adıyaman (Map 3).

nemruticum

- $\quad o^{\dagger}$ : aedeagus smaller, $0.24 \mathrm{~mm}$ long, and with internal structures shaped as in Fig. 56. Gaziantep (Map 3).

kartalicum

\section{Cephennium perispinctum group}

Species of moderate size and relatively robust habitus; body length 1.1-1.4 mm. Body of dark-reddish to dark-brown colouration. Eyes usually composed of approximately ten, rarely fewer ommatidia. Elytra with relatively large and more or less strongly transverse tomentose impressions anteriorly; humeral carina weakly pronounced and rather short, approximately as long as the combined length of the basal 2-3 antennomeres.

$\sigma^{\star}$ : protibia subapically strongly curved or angled and distinctly excavate on inner side (exception: C. immu- tatum); metaventrite flattened or shallowly impressed; aedeagus long and slender, $0.38-0.66 \mathrm{~mm}$ long; ventral process apically with more or less pronounced median extension (Figs 25-35); internal sac with weakly sclerotized structures, without distinct spines; parameres gradually tapering apicad and with long apical seta.

Species of the C.perispinctum group are regionally or locally endemic in Northwest Turkey, South Turkey, Southeast Bulgaria, and the Caucasus region (Georgia, Azerbaijan).

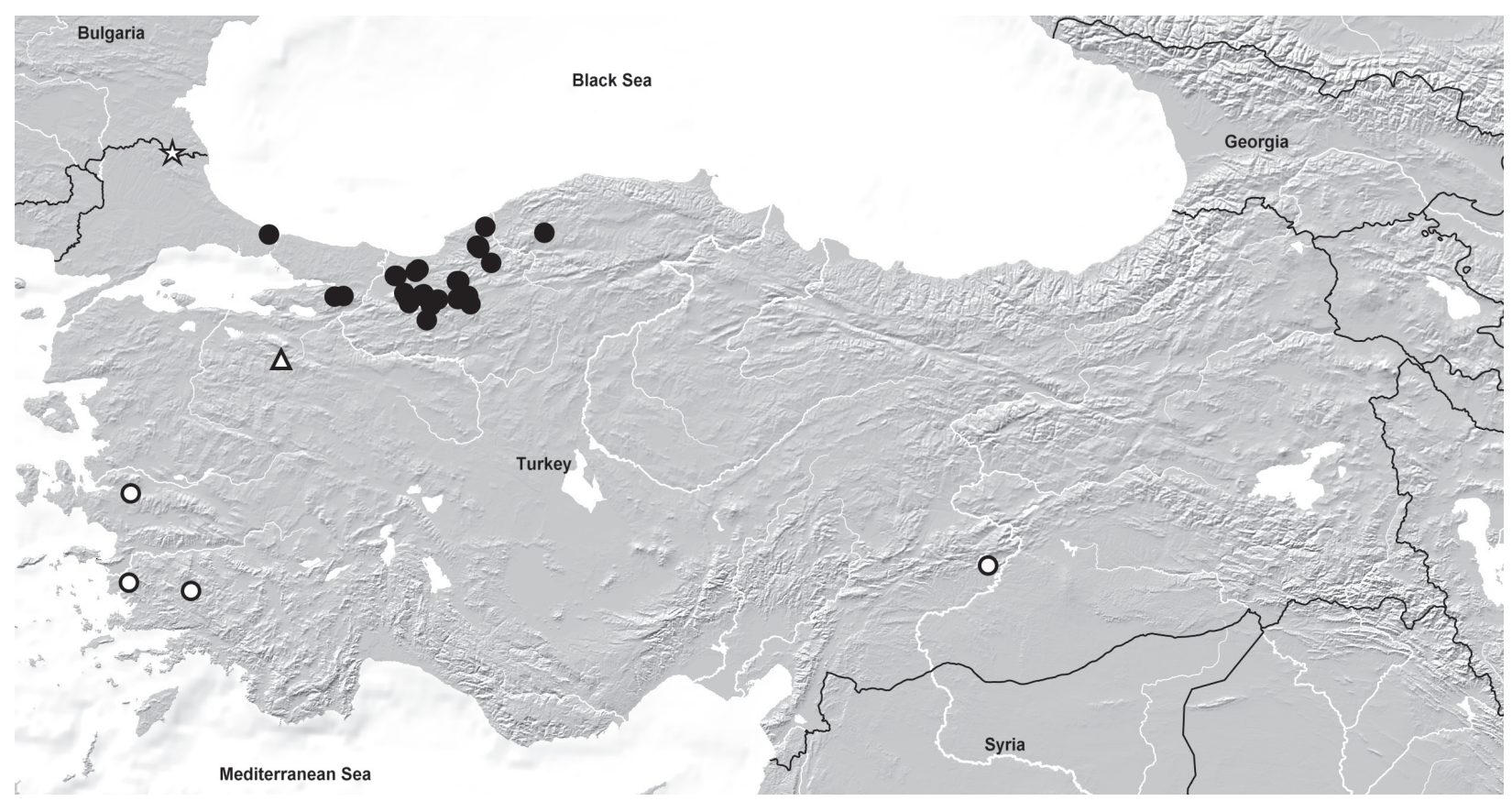

Map 1: Distributions of species of the Cephennium perispinctum group: C. bodemeyeri (black circles); C. liguliferum (white star); C. infractum (white triangle); C. immutatum (white circles). 
Cephennium bodemeyeri ReITTER, 1903, stat. nov. (Figs 1, 29-31, Map 1)

Cephennium (Megaloderus) bodemeyeri ReItTeR, 1903: 222.

Material examined: Turkey: Istanbul: $30^{\lambda} o^{\lambda}, 3$ ㅇ Belgrad Orman1, 41 $12^{\prime} 52^{\prime \prime} \mathrm{N}, 28^{\circ} 58^{\prime} 17^{\prime \prime} \mathrm{E}, 130 \mathrm{~m}, 7-8$. IV.2010, leg. Brachat \& Meybohm. Kocaeli: $10^{*}, 2$ 우, Pazarçayırı, 40³7'43"N, 3003'36"E, $720 \mathrm{~m}$, 5.V.2012, leg. Brachat \& Meybohm. Sakarya: $4 o^{\top} o^{\star}, 4$ 우 우, $17 \mathrm{~km}$ N Hendek, $40^{\circ} 52^{\prime} 30^{\prime \prime} \mathrm{N}, 30^{\circ} 46^{\prime} 16^{\prime \prime} \mathrm{E}, 850 \mathrm{~m}, 3 . \mathrm{V} .2012$, leg. Brachat \& Meybohm (cAss); $30^{\top} o^{\top}, 3$ 우 ㅇ, $14 \mathrm{~km}$ N Hendek, 4052'10"N, 3044'41"E, $700 \mathrm{~m}, 3 . V .2012$, leg. Brachat \& Meybohm; $10^{\star}, 2$ 우 우 [1 teneral], $4 \mathrm{~km} \mathrm{~S}$ Dikmen, 4040'21"N, 3054'22"E, 1275 m, 4.V.2012, leg. Brachat \& Meybohm; $10^{\star *}, 2 \mathrm{~km}$ W Dikmen, 4041'57"N, 3053'19"E, 700 m, 4.V.2012, leg. Brachat \& Meybohm. Düzce: $10^{\star}, 2$ ㅇ 우 [ 1 teneral], $26 \mathrm{~km} \mathrm{~S}$ Düzce, $40^{\circ} 40^{\prime} 43^{\prime \prime} \mathrm{N}$, $31^{\circ} 08^{\prime} 48^{\prime \prime E}, 1200 \mathrm{~m}, 1 . V .2012$, leg. Brachat \& Meybohm; $10^{*}, 2$ ㅇ 우 $23 \mathrm{~km}$ S Düzce, $40^{\circ} 41^{\prime} 21^{\prime \prime} \mathrm{N}, 31^{\circ} 08^{\prime} 18^{\prime \prime} \mathrm{E}$, $1020 \mathrm{~m}, 1 . \mathrm{V} .2012$, leg. Brachat \& Meybohm; $1 \mathrm{o}^{*}$,

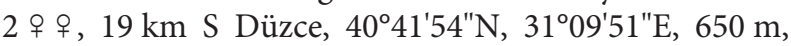
1.V.2012, leg. Brachat \& Meybohm; $10^{*}, 3$ 우 우, Kaplandede Dağ1, 4057'04"N, 3104'03"E, 1100 m, 2.V.2012, leg. Brachat \& Meybohm; $2 \sigma^{\star} \sigma^{\star}, 2$ 우, Kaplandede Dağ 1 , $40^{\circ} 55^{\prime} 24^{\prime \prime} \mathrm{N}, 31^{\circ} 01^{\prime} 53 " \mathrm{E}, 710 \mathrm{~m}, 2 . \mathrm{V} .2012$, leg. Brachat \& Meybohm. Bolu: $30^{\top} \sigma^{\star}, 2$ 우, $8 \mathrm{~km}$ NE Abant, $40^{\circ} 38^{\prime} 48^{\prime \prime} \mathrm{N}, 31^{\circ} 21^{\prime} 35^{\prime} \mathrm{E}, 1010 \mathrm{~m}, 27 . I V .2012$, leg. Brachat \& Meybohm; $10^{\top}, \mathrm{S}$ Abant, 40 $35^{\prime} 05^{\prime \prime} \mathrm{N}, 31^{\circ} 16^{\prime} 13^{\prime \prime} \mathrm{E}$, $1180 \mathrm{~m}, 27 . I V .2012$, leg. Brachat \& Meybohm; $3 \sigma^{*} \sigma^{*}$, 2 우, 이 29.IV.2012, leg. Brachat \& Meybohm; $1 \sigma^{\star}$, Bolu-Yı̆̆ılca, $40^{\circ} 50^{\prime} 55^{\prime \prime} \mathrm{N}, 31^{\circ} 37^{\prime} 17^{\prime \prime} \mathrm{E}, 1020 \mathrm{~m}$, 29.IV.2012, leg. Brachat \& Meybohm; $20^{\star} o^{\star}$ [1 teneral], 2 우, 이 Bolu-Y̌ğlca, $40^{\circ} 50^{\prime} 51^{\prime \prime} \mathrm{N}, 31^{\circ} 36^{\prime} 40^{\prime \prime E}, 980 \mathrm{~m}, 29 . I V .2012$, leg. Brachat

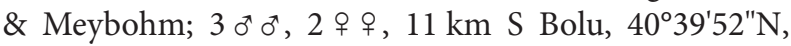
$31^{\circ} 37^{\prime} 50 " \mathrm{E}, 1080 \mathrm{~m}, 30 . \mathrm{IV} .2012$, leg. Brachat \& Meybohm; $10^{\star}, 2$ ㅇ 우, $10 \mathrm{~km} \mathrm{~S}$ Bolu, $40^{\circ} 40^{\prime} 03^{\prime \prime} \mathrm{N}, 31^{\circ} 38^{\prime} 06^{\prime \prime} \mathrm{E}, 1020 \mathrm{~m}$, 30.IV.2012, leg. Brachat \& Meybohm; $10^{\top}, 7 \mathrm{~km} \mathrm{~S}$ Bolu, $40^{\circ} 40^{\prime} 10^{\prime \prime} \mathrm{N}, 31^{\circ} 37^{\prime} 58^{\prime \prime} \mathrm{E}, 950 \mathrm{~m}$, oak and beech forest, sifted, 31.III.2010, leg. Assing; $40^{\star} \sigma^{\star}, 40 \mathrm{~km}$ W Mudurnu, $40^{\circ} 35^{\prime} 44^{\prime \prime} \mathrm{N}, 30^{\prime} 57^{\prime} 50^{\prime E} \mathrm{E}, 650 \mathrm{~m}$, 23.IV.2014, leg. Brachat \& Meybohm; $10^{\star}, 3$ 우 우, Mudurnu, Vakıfaktaş, $40^{\circ} 25^{\prime} 43^{\prime \prime} \mathrm{N}$, $31^{\circ} 13^{\prime} 13 " \mathrm{E}, 1180-1220 \mathrm{~m}, 23 . I V .2014$, leg. Brachat \& Meybohm; $60^{\star} o^{\star}, 8$ 우 우, same data, but 24.IV.2014; $10^{\star}$, Kartalkaya, 40³7'03"N, 31 ${ }^{\circ} 48^{\prime} 32$ "E, 1720 m, 25.IV.2014, leg. Brachat \& Meybohm; $20^{\star} 0^{\star}, 2$ 우 운, Kartalkaya, $40^{\circ} 41^{\prime} 57^{\prime \prime} \mathrm{N}, 31^{\circ} 46^{\prime} 07^{\prime \prime E}, 1400 \mathrm{~m}$, 25.IV.2014, leg. Brachat \& Meybohm; $1 \sigma^{\star}$, Bolu pass, 900 m, 20.VI.1989, leg. Wolf. Zonguldak: $4 o^{\top} o^{\star}, 4$ ㅇ ㅇ, Devrek, $41^{\circ} 13^{\prime} 20^{\prime \prime} \mathrm{N}, 31^{\circ} 53^{\prime} 06^{\prime \prime} \mathrm{E}$, 590 m, 2.V.2014, leg. Brachat \& Meybohm; 8 o $^{\star}$, 3 우 우, same data, but 3.V.2014; $30^{\top} \sigma^{\star}$, Devrek, $41^{\circ} 12^{\prime} 27^{\prime \prime} \mathrm{N}$, 31 53'59"E, 550 m, 3.V.2014, leg. Brachat \& Meybohm; $10^{\star}, 1$ ㅇ, $15 \mathrm{~km}$ W Devrek, 41 ${ }^{\circ} 13^{\prime} 45^{\prime \prime} \mathrm{N}, 31^{\circ} 51^{\prime} 45^{\prime \prime} \mathrm{E}$, beech forest with rhododendron undergrowth, sifted, 26.III.2010, leg. Assing; 2 우 으, W Çaycuma, $41^{\circ} 25^{\prime} 53^{\prime \prime} \mathrm{N}$, $31^{\circ} 57^{\prime} 51^{\prime \prime E}, 570$ m, 1.V.2014, leg. Brachat \& Meybohm. Karabük: 1 오 Safranbolu, $41^{\circ} 23^{\prime} 31^{\prime \prime N}, 32^{\circ} 47^{\prime} 16^{\prime \prime E}$,
950 m, 29.IV.2014, leg. Brachat \& Meybohm; 1 ơ $^{\star} 30 \mathrm{~km}$

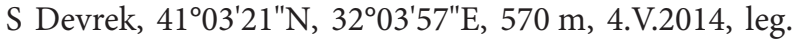
Brachat \& Meybohm. All examined specimens are deposited in cAss.

Material examined and identified by C. Besuchet: Type material: $3 \sigma^{\star} \sigma^{\star}, 2$ 우: "Asia Minor, Goek-Dagh., V. Bodemeyer" (HNHM). Additional material: Turkey: Istanbul: 17 o $\sigma^{\star}, 12$ ㅇ ㅇ , Belgrad Ormanı, leg. Apfelbeck, Schubert (NHMW). Kocaeli: 1 ㄲ, 3 우 우, 2 exs., "GoekDagh" [ $40^{\circ} 37^{\prime} \mathrm{N}, 29^{\circ} 56^{\prime} \mathrm{E}$ ], leg. v. Bodemeyer (various collections).

Comment: Based on an unspecified number of syntypes from "Anatolien: Goek-Dagh und Alem-Dagh", C. bodemeyeri was originally described as a distinct species (Reitter 1903). It was subsequently attributed to C. perispinctum Kolenati, 1846 as a subspecies (VÍt \& Besuchet 2004).

While the distribution of C. bodemeyeri is confined to Northwest Turkey, C. perispinctum is widespread and not uncommon in Georgia and has also been recorded from Azerbaijan. The previous record from Armenia (VÍt \& Besuchet 2004) is most likely based on Besuchet (unpublished notes), who erroneously attributed specimens labelled "Armen. Geb." to Armenia rather than to Georgia (see Assing \& Schülke 2019). In any case, the distributions of both taxa are separated by a distance of nearly $800 \mathrm{~km}$, thus casting doubt on the previous subspecific concept. A comparison of the aedeagi of C. bodemeyeri and C. perispinctum eventually revealed that they are similar, but not identical, and distinguished particularly by the shape of the apex of the median lobe in ventral view (C. bodemeyeri: ventral process more strongly constricted subapically and apico-laterally not distinctly angled). For comparison see the aedeagus of C. perispinctum in Figs 25-26. A third argument comes from the discovery of a third similar species of the same species group, which was recently collected in Southeast Bulgaria and which is described (as C. liguliferum) in an appendix at the end of this paper.

In consequence, the above observations suggest that these taxa represent distinct, albeit closely related species rather than subspecies.

Diagnosis: Body length 1.2-1.4 mm; length of pronotum $0.39-0.45 \mathrm{~mm}$; width of pronotum $0.50-0.57 \mathrm{~mm}$; length of antennae approximately $0.6 \mathrm{~mm}$. Habitus as in Fig. 1. Colouration: body reddish to dark-brown with the elytra often somewhat darker than head and pronotum.

Eyes composed of approximately ten ommatidia. Antenna with pronounced club formed by antennomeres IX-XI; antennomere VIII slightly smaller than antennomere VII and much smaller than antennomere IX; antennomere XII nearly twice as long as broad.

Pronotum 1.20-1.25 times as broad as long, broadest in anterior half, and strongly convex in cross-section; lateral margins straight or indistinctly sinuate in posterior half. 
Elytra each anteriorly with a transverse impression with long and tomentose whitish pubescence; humeral carina nearly obsolete.

$0^{\top}$ : protibia subapically distinctly curved and somewhat flattened and excavate on inner side; aedeagus (Figs 29-31) 0.50-0.55 mm long; ventral process apically extending into a long and narrow median process in ventral view; internal sac with a pair of moderately sclerotized oblong structures; paramere bisinuate, far from reaching apex of ventral process, and apically with a long curved seta.

Distribution and natural history: The known distribution of C. bodemeyeri is confined to Northwest Turkey from Istanbul province in the west to Karabük in the east (Map 1). The altitudes range from 130 to $1720 \mathrm{~m}$, from the beech forest to the fir forest zone. Some specimens collected at the end of April and in the beginning of May are teneral.

\section{Cephennium fractum spec. nov. urn:Isid:zoobank.org:act:26CE8301-2927-4893-B93E-9F2BEF4F7F07 (Figs 2-3, 32, 46, Map 2)}

Type material examined: Holotype ơ: "N39 50 '08 E2825'31 (19), TR Bursa 16.4.2010, Devecikonagi 640 m, leg. Brachat \& Meybohm / Holotypus ơ Cephennium fractum sp. n., det. V. Assing 2020" (cAss). Paratypes: $2 o^{\star} o^{\star}, 2$ 우: “N4006'47 E02904'10 (21), TR Bursa 17.4.2010, Uludag $1430 \mathrm{~m}$, leg. Brachat \& Meybohm" (cAss); 4 ㅇ 우: “N40³1'40 E02952'10 (27), TR Bursa 20.4.2010, Samanli Daglari $740 \mathrm{~m}$, leg. Brachat \& Meybohm" (cAss); 1 우 “N40³0'41 E02949'50 (26), TR Bursa 19.4.2010, Samanli Daglari 720 m, leg. Brachat \& Meybohm" (cAss); $10^{7}$, 1 ㅇ: “TR - Balikesir (11), Kaz Daği-Gebiet, ca. 20 km NO Edremit, Kuruçam Tepe, 708 m, 13.IV.2010 / N39²41'39,2

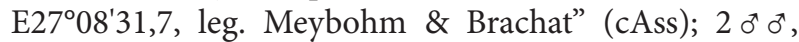
2 우 우: “N40³8'47 E3003'25 (2), TR Kocaeli 22.4.2014, Pazarcayiri $880 \mathrm{~m}$, Brachat \& Meybohm" (cAss); $10^{*}$, 1 ㅇ: “N40³7'43 E3003'36, TR Kocaeli 25.4.2012, Pazarcayiri $720 \mathrm{~m}$, Brachat \& Meybohm (5)" (cAss); $10^{*}$ : “N40³8'47 E3003'25, TR Kocaeli 25.4.2012, Pazarcayiri $880 \mathrm{~m}$, Brachat \& Meybohm (6)" (cAss); 1 o , 2 ㅇ ㅇ: “N40³9'04 E3003'42, TR Kocaeli 24.4.2012, Kartepe $1030 \mathrm{~m}$, Brachat \& Meybohm (1)” (cAss); 1 o $^{\star}, 3$ ㅇ 우 “N40³8'54 E3005'32, TR Kocaeli 5.5.2012, Kartepe 1270 m, Brachat \& Meybohm (35)” (cAss); 1 o $^{\star}, 2$ ㅇ 우: “N40³9'24 E3004'46, TR Kocaeli 24.4.2012, Kartepe 1140 m, Brachat \& Meybohm (2)” (cAss); 1 ㅇ : “N3942'45 E27 $10^{\prime} 23$ (14), TR Canakkale, 14.4.2010, Kurucam Tepe $600 \mathrm{~m}$, leg. Brachat \& Meybohm” (cAss).

Etymology: The specific epithet is the past participle of the Latin verb frangere (to fold, to break) and alludes to the subapically distinctly curved male protibiae.
Description: Body length $1.1-1.3 \mathrm{~mm}$; length of pronotum $0.38-0.42 \mathrm{~mm}$; width of pronotum $0.45-0.51 \mathrm{~mm}$; length of antennae $0.55-0.60 \mathrm{~mm}$. Habitus as in Figs 2-3. Colouration: body reddish to brown, often with the elytra somewhat darker than the head and pronotum.

Eyes composed of 6-8 ommatidia. Antenna of similar shape as in C. bodemeyeri.

Pronotum approximately 1.2 times as broad as long, broadest in anterior half, and moderately convex in crosssection; lateral margins straight in posterior half.

Elytra noticeably broader than pronotum, anteriorly with a subcircular impression with tomentose whitish pubescence; humeral carina fine, approximately as long as the combined length of the basal three antennomeres.

$\sigma^{\star}$ : protibia distinctly bent subapically and flattened in subapical portion, apically dilated; metaventrite extensively flattened, but not distinctly impressed; aedeagus (Figs 32, 46) long and slender, $0.60-0.66 \mathrm{~mm}$ long; ventral process constricted in the middle and apically with a moderately long apical extension in ventral view; internal sac with weakly sclerotized small structures; paramere long and straight, extending to apical fifth of ventral process, with a long and weakly curved apical seta.

Comparative notes: This species is distinguished from the similar C. bodemeyeri by slightly shorter antennae, slightly smaller eyes, smaller and more circular anterior tomentose impressions on the elytra, subapically more sharply bent male protibiae, and a longer and more slender aedeagus with a differently shaped ventral process with a shorter apical extension, by straight parameres, and by internal structures of different shapes.

Distribution and natural history: The distribution is confined to Bursa, Balıkesir, Kocaeli, and Çanakkale provinces, Northwest Anatolia (Map 2). The specimens were sifted from litter in beech and hornbeam forests, mostly with rhododendron undergrowth and often in dark stream valleys. The altitudes range from 600 to $1430 \mathrm{~m}$. In one locality in Kocaeli, the species was collected together with C. bodemeyeri.

\section{Cephennium infractum spec. nov. urn:Isid:zoobank.org:act:E222C4A2-D6AC-48FF-AC4C-B274EF405209 (Figs 4, 33, 47, Map 1)}

Type material examined: Holotype $o^{\star}$ : "N39 $56^{\prime} 15$ E29 $15^{\prime} 25$ (24), TR Bursa 18.4.2010, Kocayayla 1200 m, leg. Brachat \& Meybohm / Holotypus o Cephennium infractum sp. n., det. V. Assing 2020" (cAss). Paratypes: $10^{\star}, 4$ 우 우: same data as holotype (cAss).

Etymology: The specific epithet is the past participle of the Latin verb infringere (to fold, to break) and alludes to the subapically distinctly curved male protibiae. 

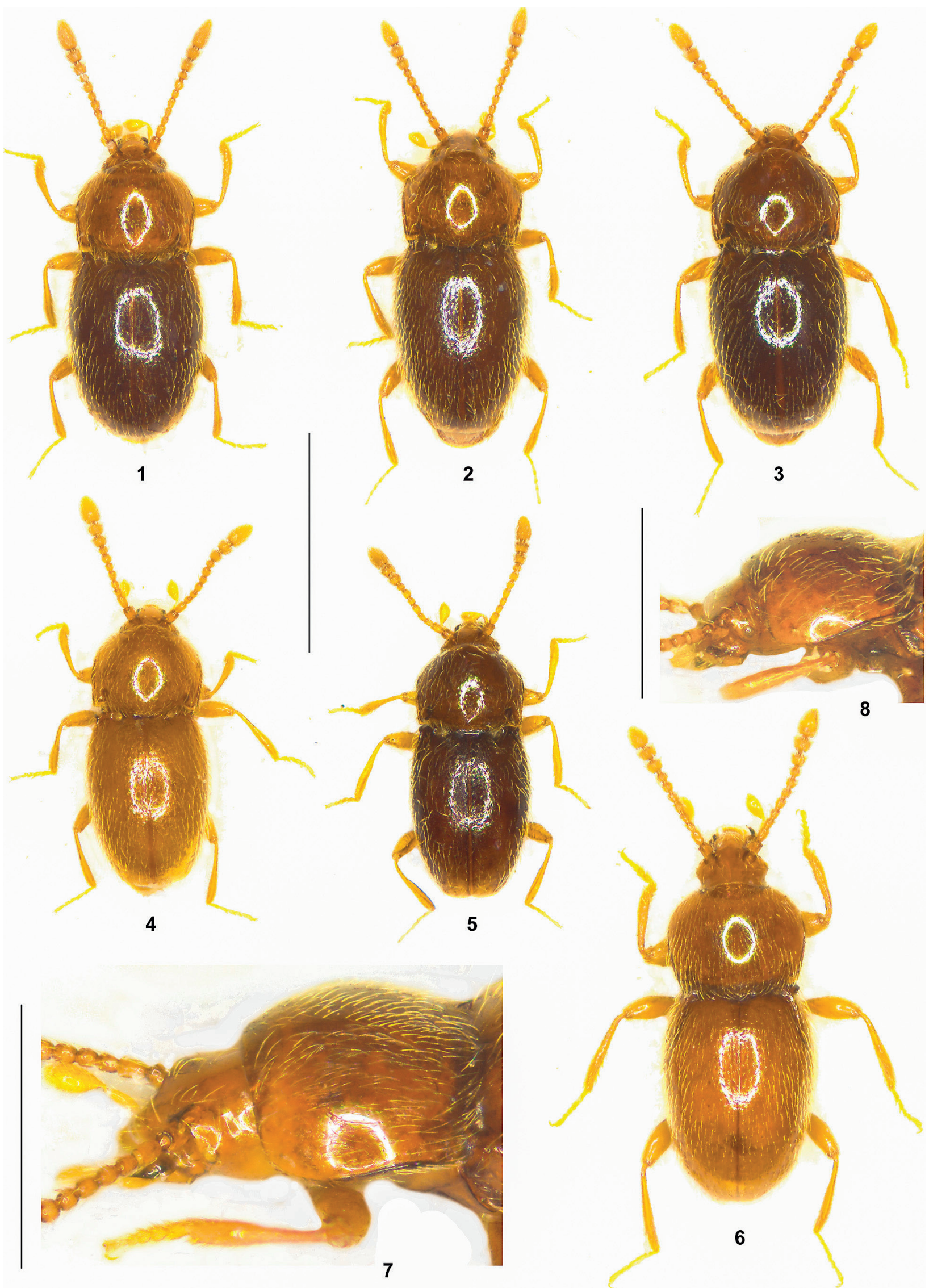

Figs 1-8: Male habitus in dorsal view (1-6) and head and pronotum in lateral view (7-8) of Cephennium bodemeyeri (1), C. fractum (2-3), C. infractum (4), C. immutatum (5), C. ericinum (6-7), and C. varispinosum (8). Scale bars: 1-6: $1.0 \mathrm{~mm}$; 7-8: $0.5 \mathrm{~mm}$. 


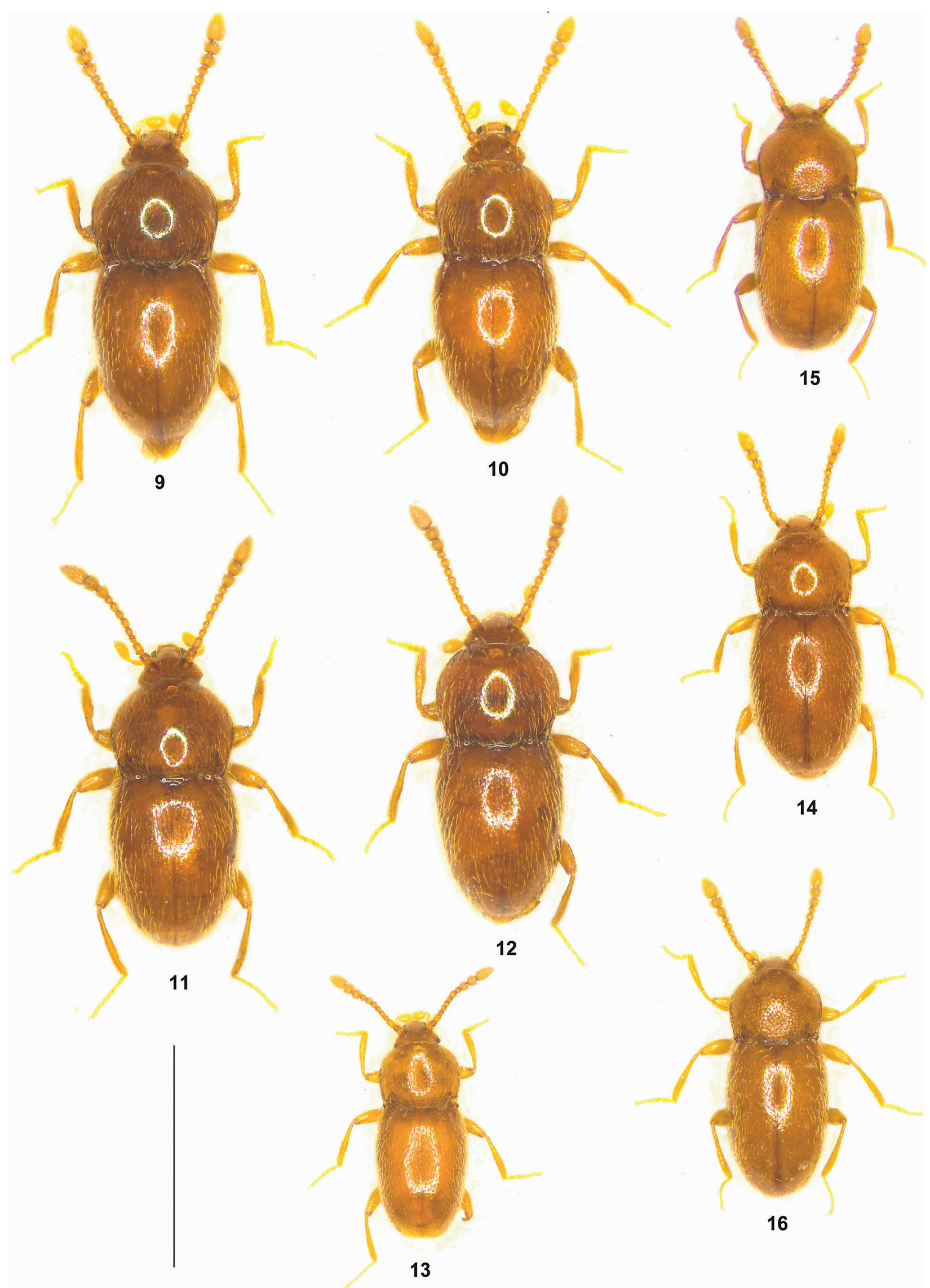

Figs 9-16: Male habitus in dorsal view of Cephennium varispinosum (9), C. victrix (10), C. spinigerum (11), C. digitale (12), C. reductum (13), C. corruptum (14), C. marasicum (15), and C. dolucanum (16). Scale bar: $1.0 \mathrm{~mm}$. 


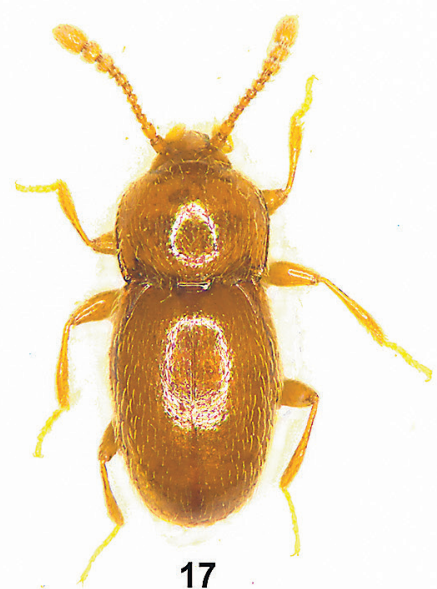

17

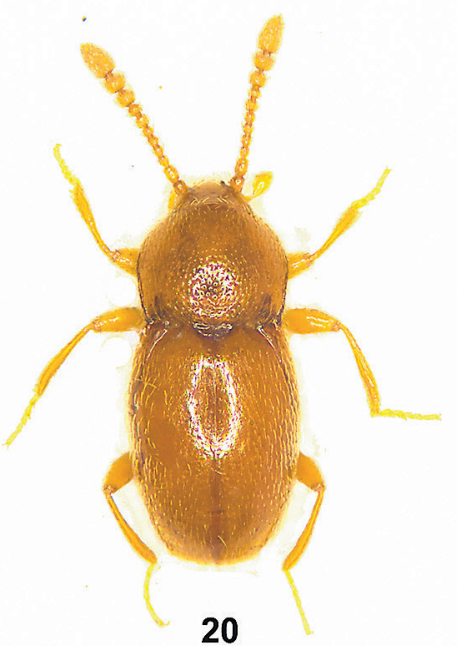

20

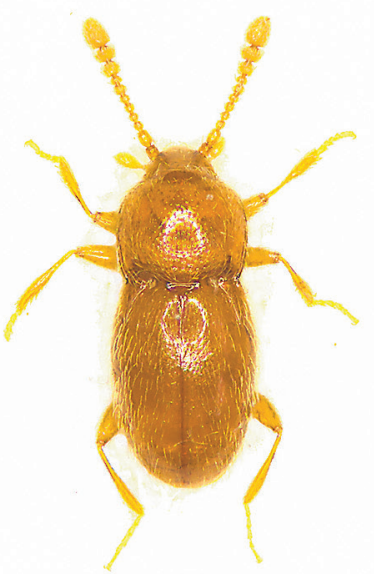

23

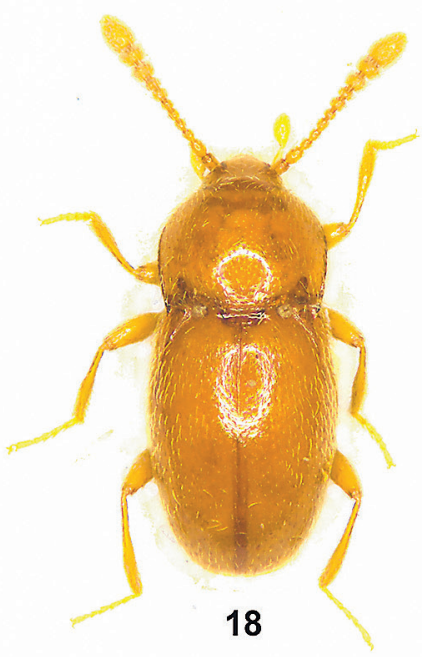

18

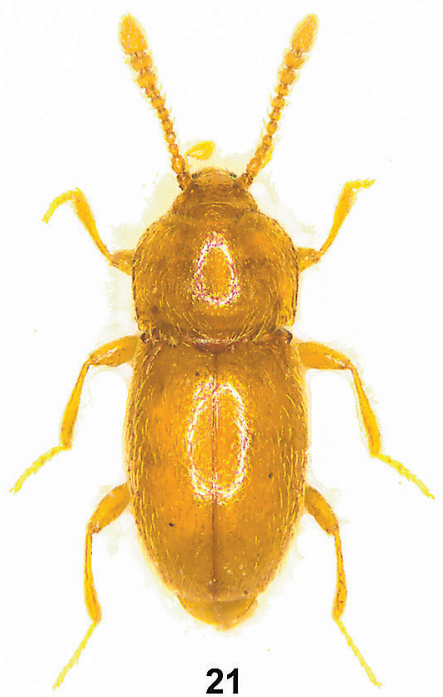

21

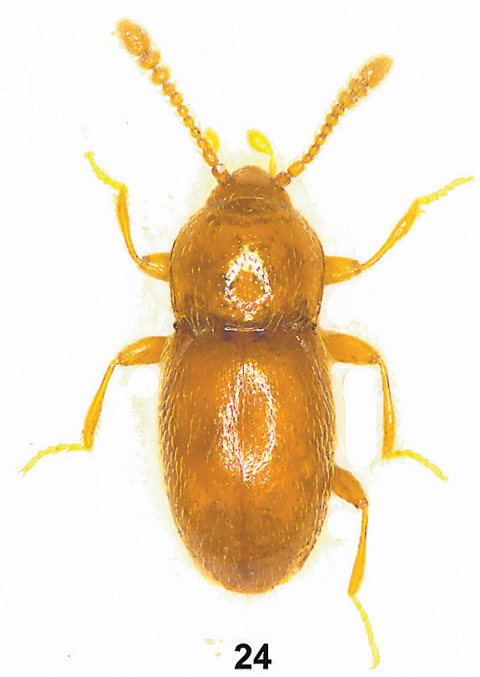

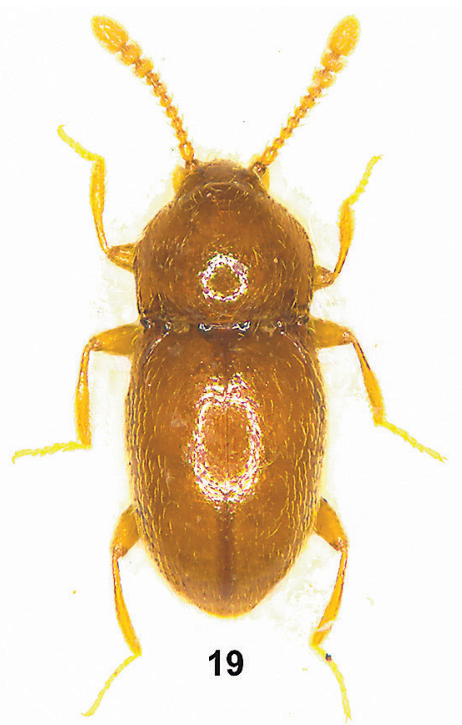

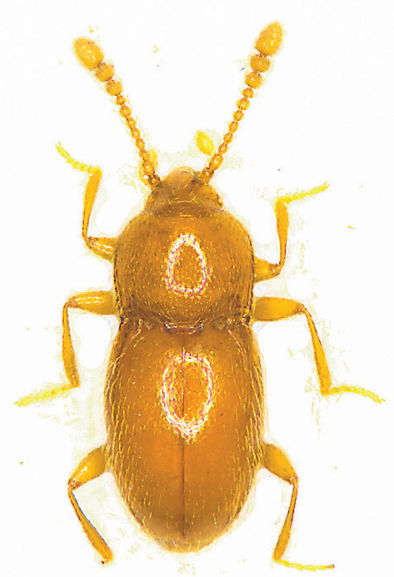

22

Figs 17-24: Male habitus in dorsal view of Cephennium fimbriatum (17), C. besucheti (18), C. affimbriatum (19), C. kartalicum (20), C. nemruticum (21), C. unguicum (22), C. deplectens (23), and C. jordanicum (24). Scale bar: $1.0 \mathrm{~mm}$. 


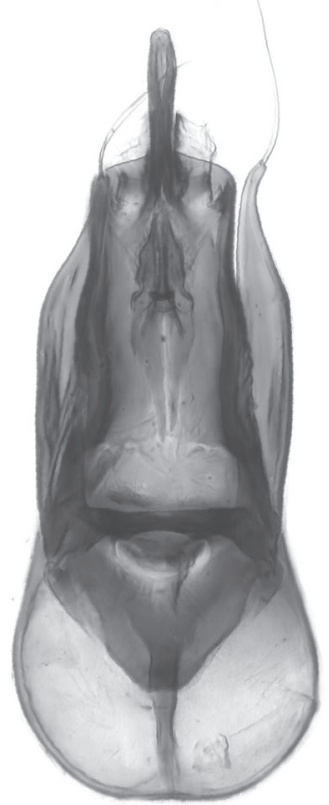

25

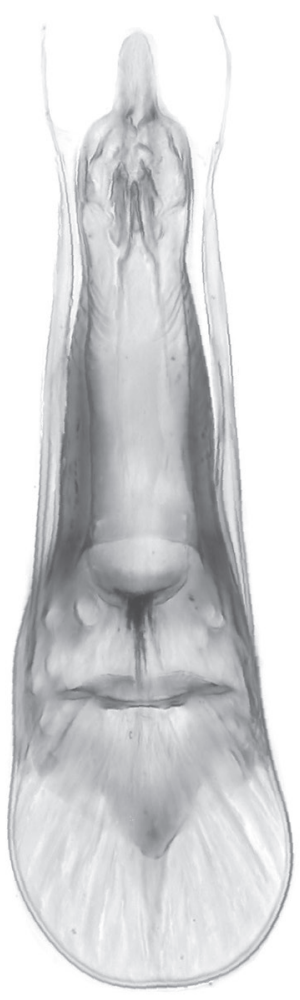

32

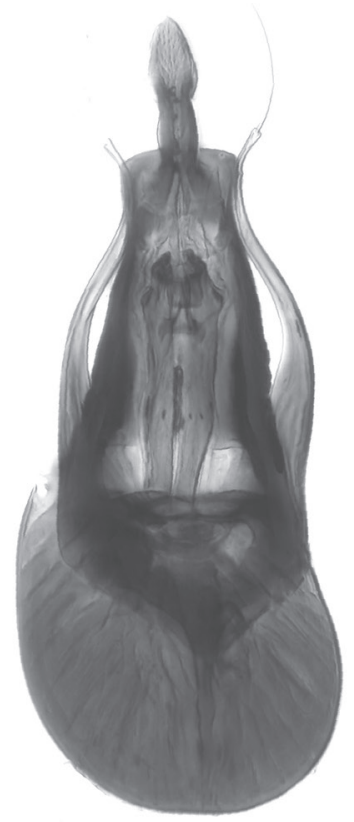

27

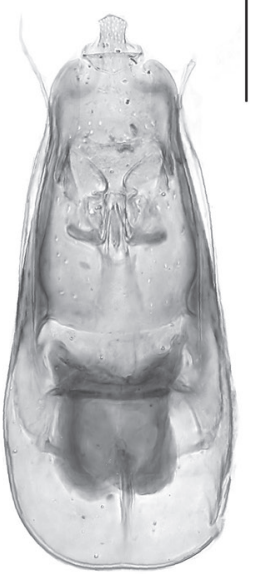

34

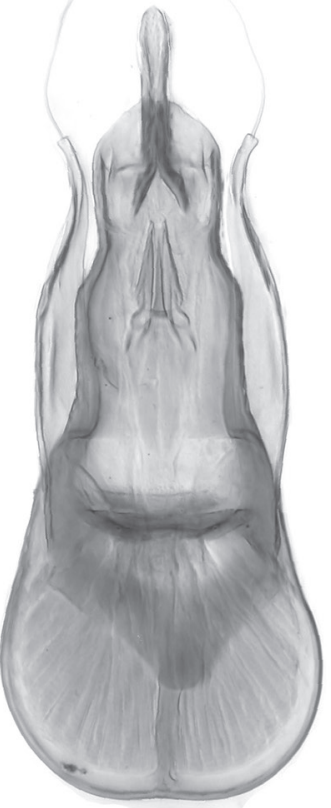

29

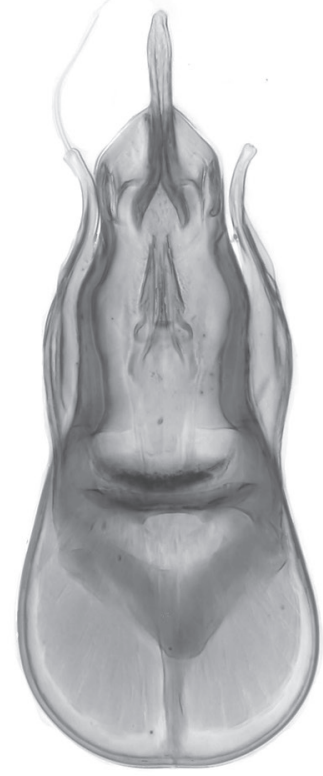

30
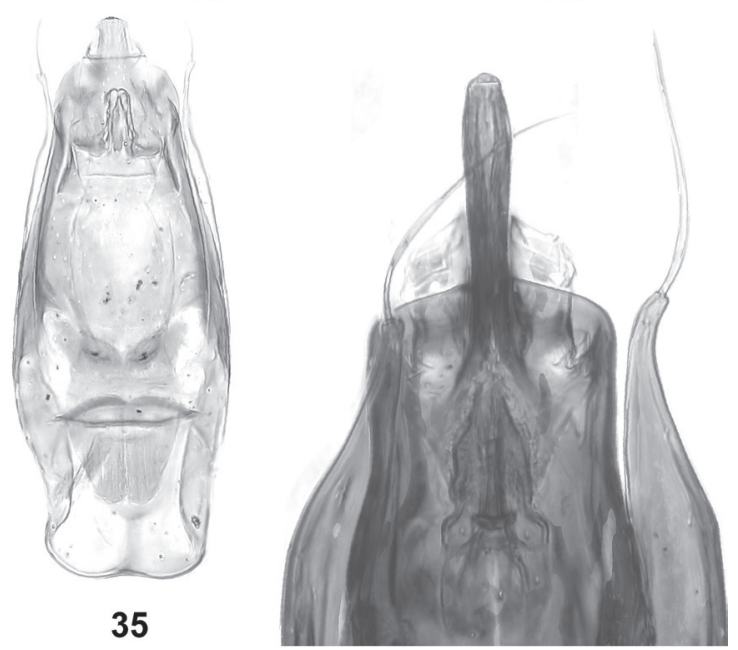

26

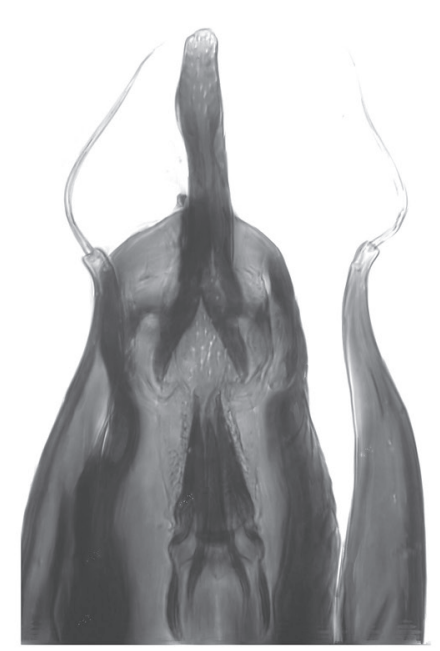

31

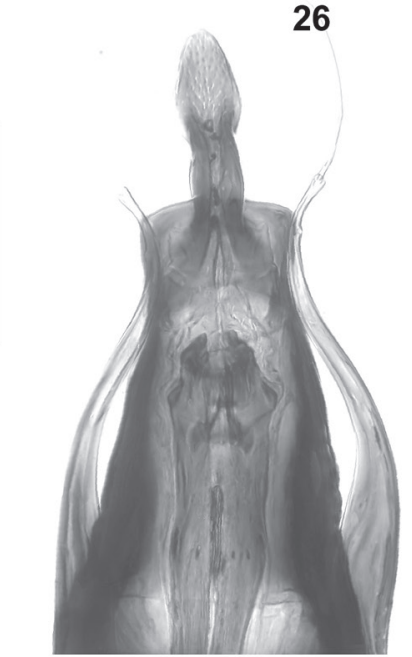

28

Figs 25-35: Aedeagus in ventral view $(25,27,29-30,32-35)$ and apical portion of aedeagus in ventral view $(26,28,31)$ of Cephennium perispinctum (25-26), C. fibuliferum (27-28), C. bodemeyeri (29-31), C. fractum (32), C. infractum (33), and C. immutatum (34-35). Scale bars: 25, 27, 29-30, 32-35: 0.2 mm; 26, 28, 31: $0.1 \mathrm{~mm}$. 


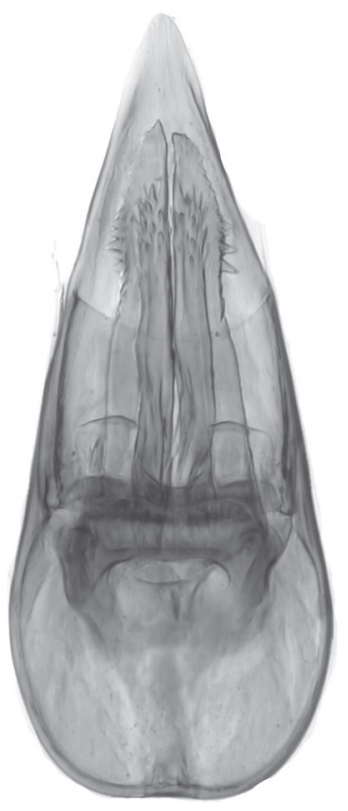

36

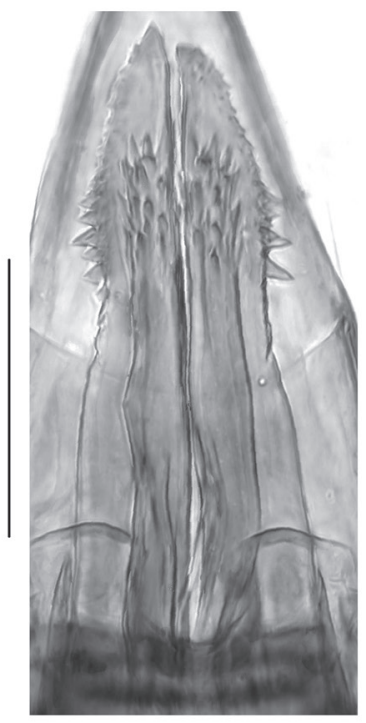

37

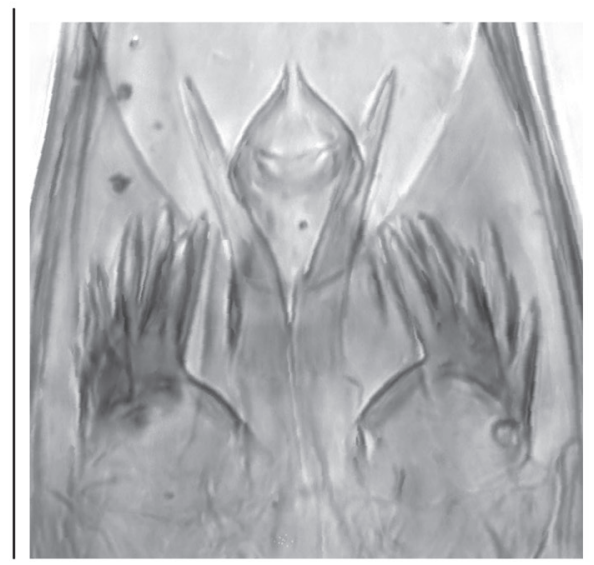

41

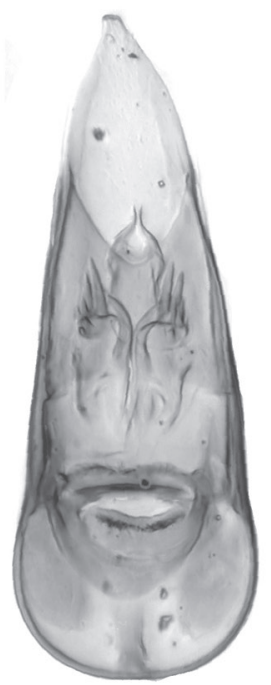

38

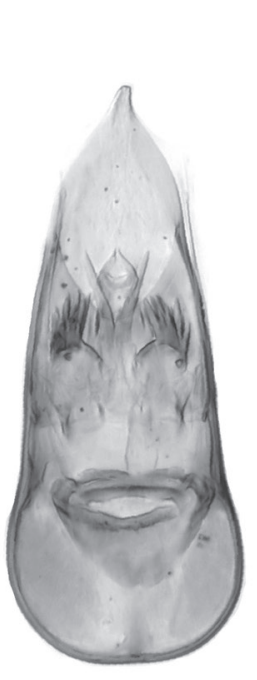

40

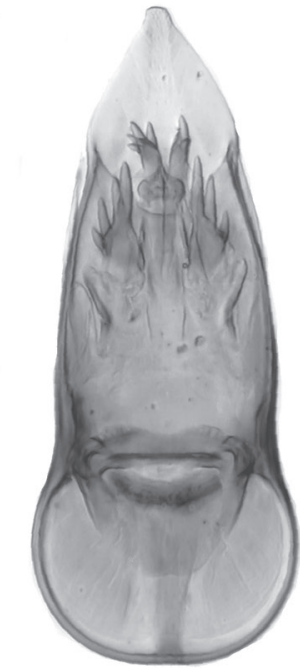

42

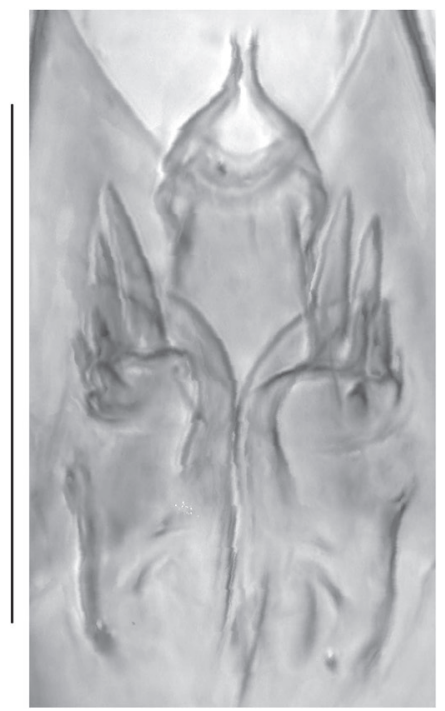

39

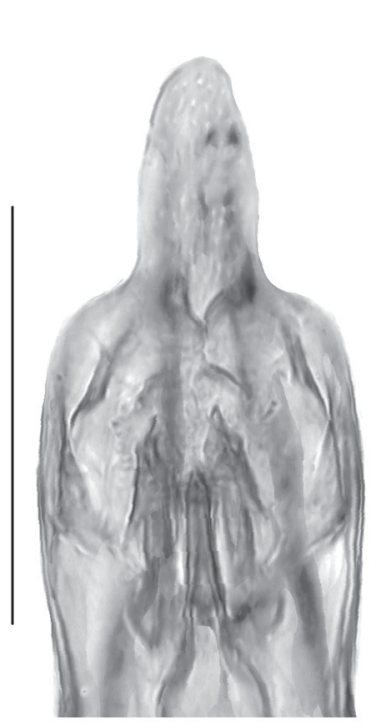

46

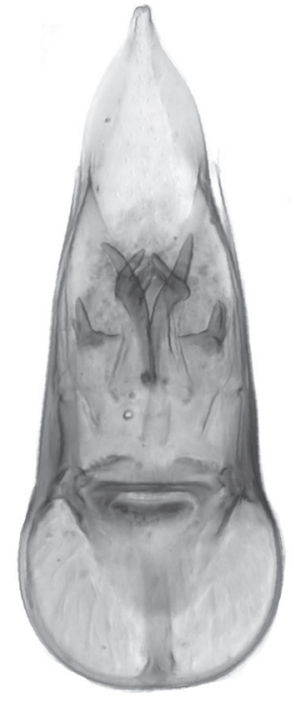

44

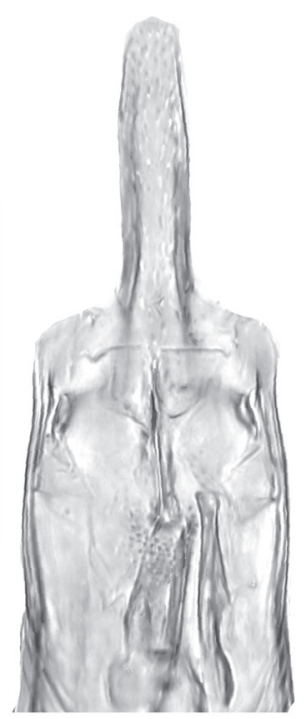

47

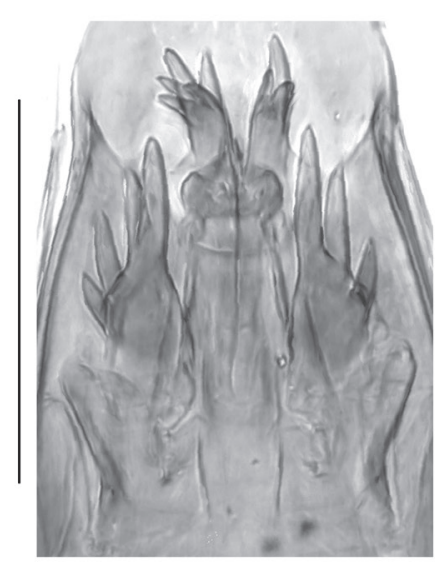

43

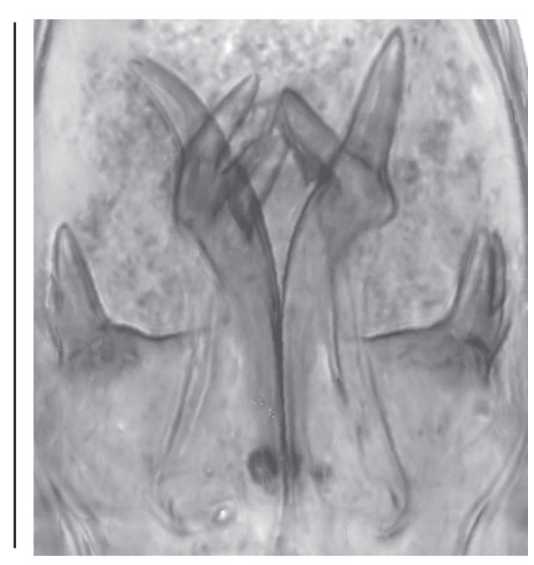

45

Figs 36-47: Aedeagus in ventral view $(36,38,40,42,44)$, internal structures of aedeagus $(37,39,41,43,45)$, and apical portion of aedeagus in ventral view (46-47) of Cephennium ericinum (36-37), C. varispinosum (38-39), C. victrix (40-41), C. spinigerum (42-43), C. digitale (44-45), C. fractum (46), and C. infractum (47). Scale bars: 36, 38, 40, 42, 44: $0.2 \mathrm{~mm}$; 37, 39, 41, 43, 45-47: $0.1 \mathrm{~mm}$. 


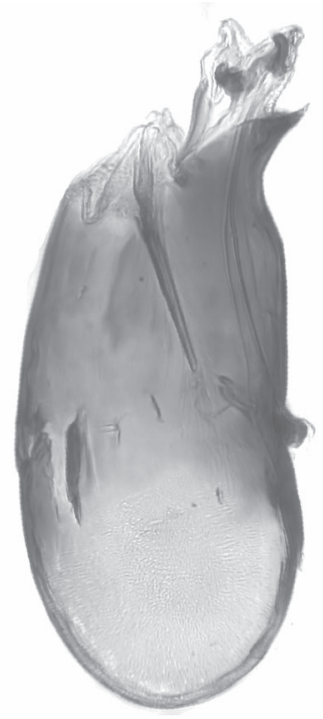

48

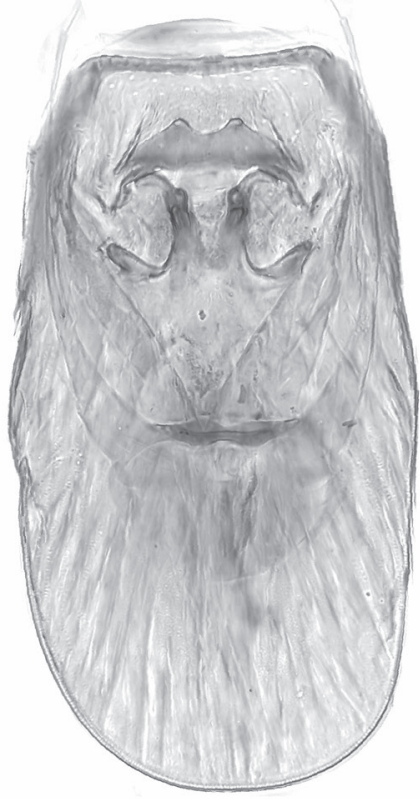

52

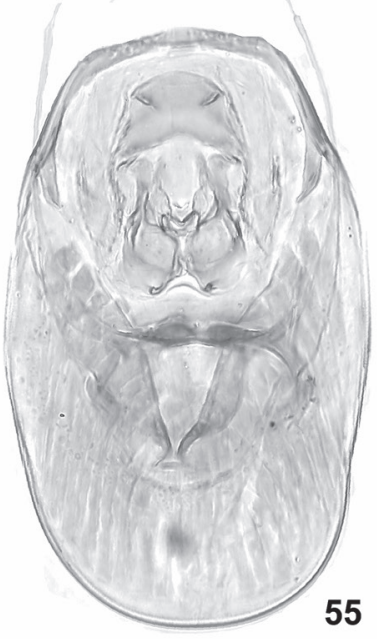

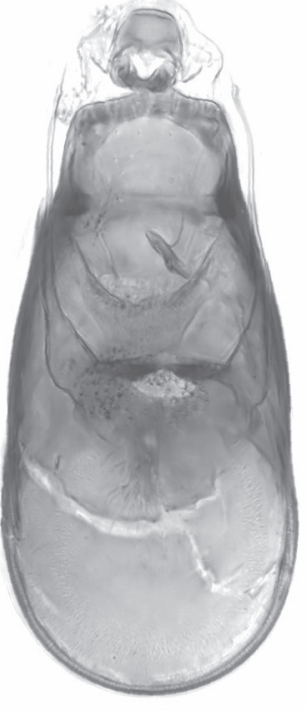

49

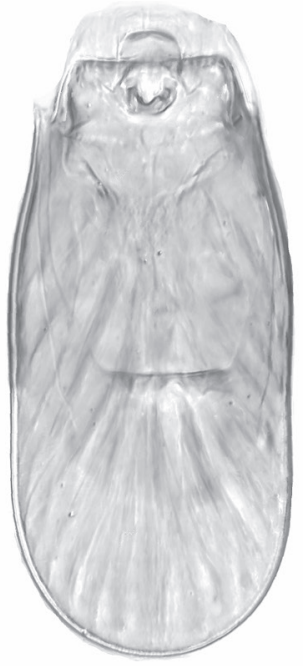

50

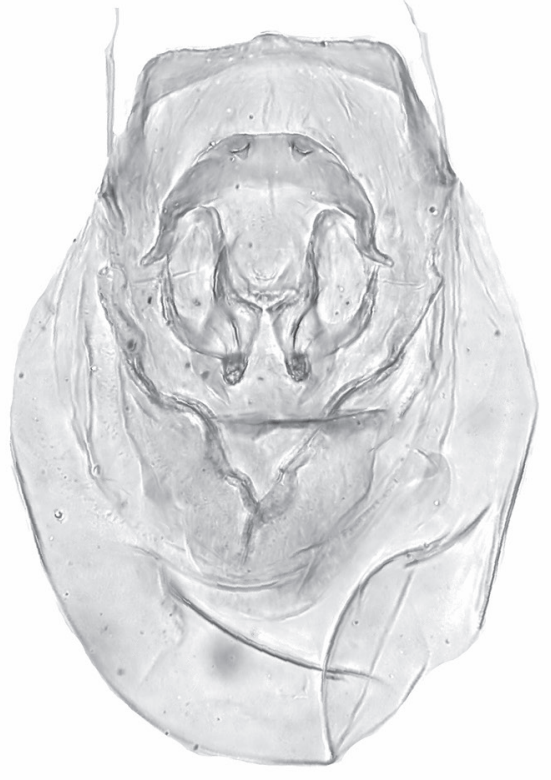

51

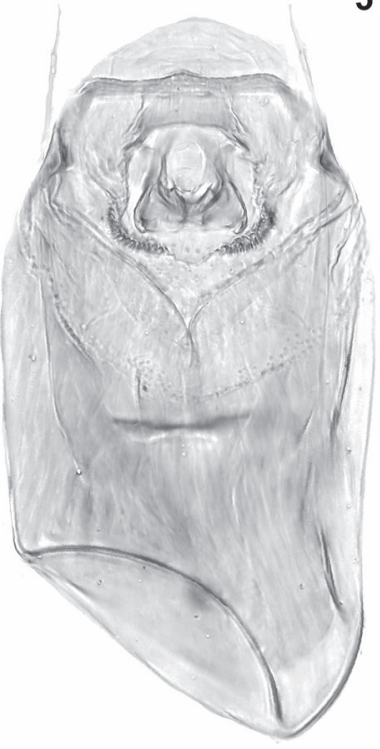

54

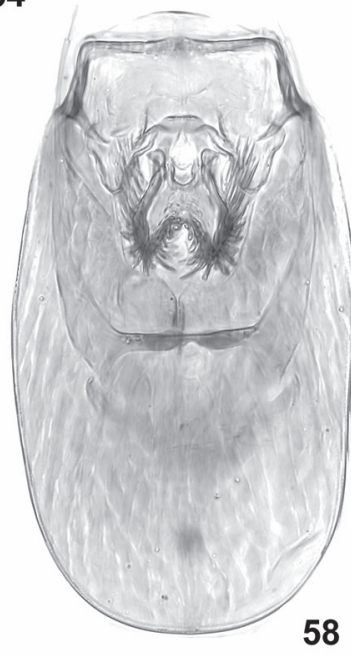

Figs 48-58: Aedeagus in lateral (48) and in ventral view (49-58) of Cephennium reductum (48-50), C. nemruticum (51), C. marasicum (52), C. dolucanum (53), C. besucheti (54), C. affimbriatum (55), C. kartalicum (56), C. corruptum (57), and C. fimbriatum (58). Scale bar: $0.1 \mathrm{~mm}$. 


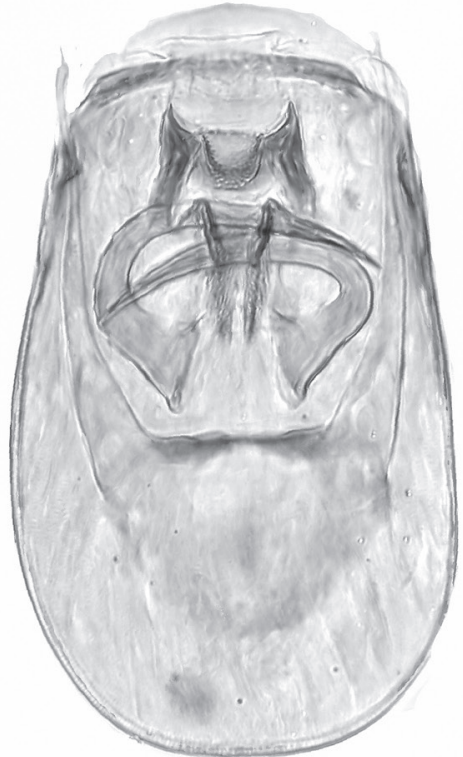

59

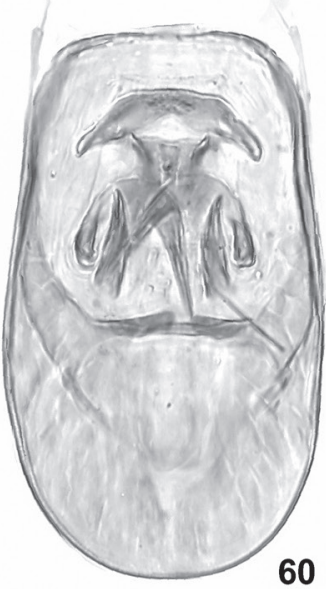

60

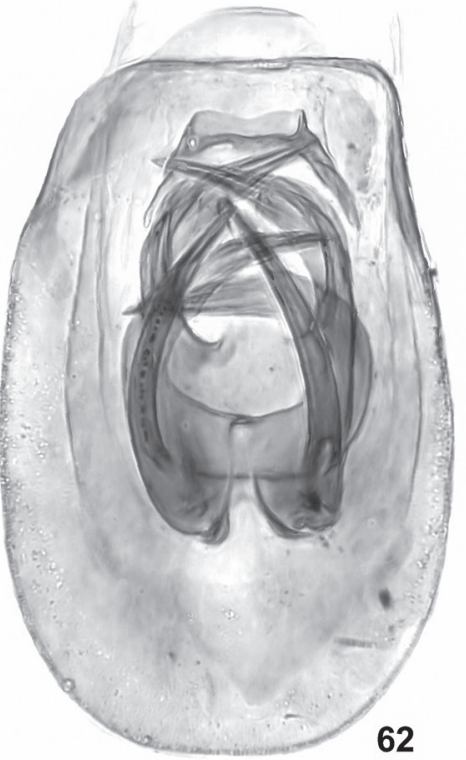

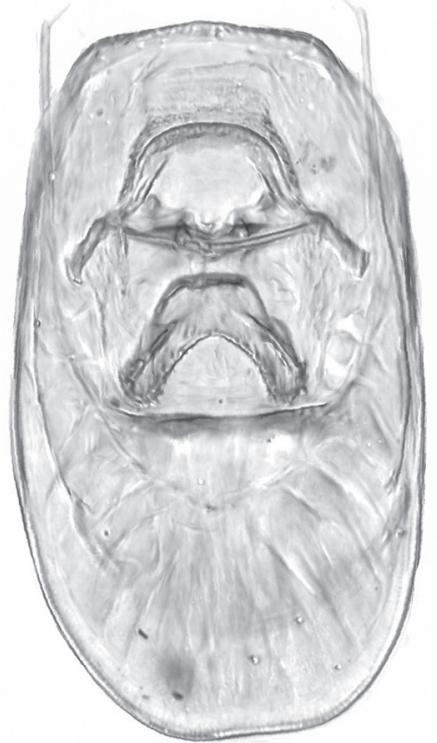

67

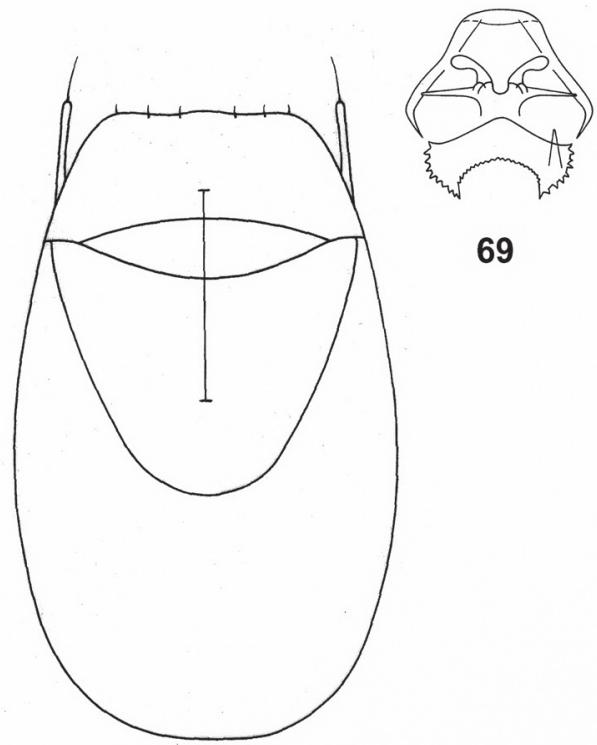

68
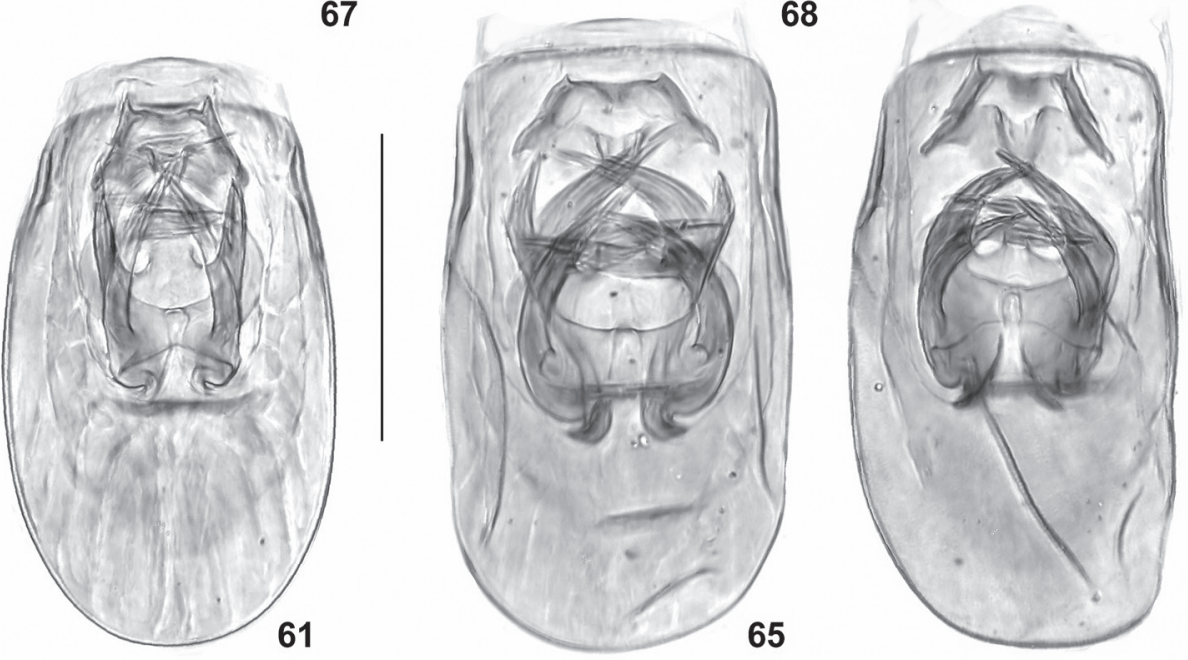

66
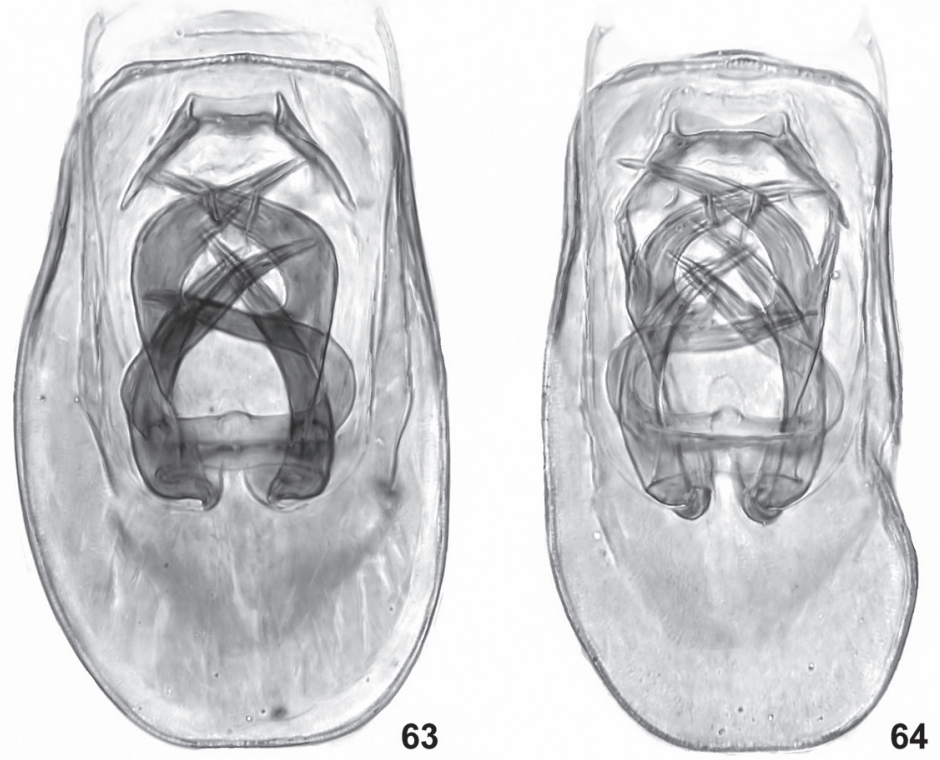

Figs 59-69: Aedeagus in ventral/dorsal view (59-68) and internal structures of aedeagus in ventral view (69) of Cephennium unguicum (59), C. deplectens (60), C. sicaferum (61), C. geminum (62-64; 62: Termessos; 63: Olimpos; 64: Kemer), C. duplum (65-66), C. jordanicum (67), and C. judaeum (68-69; drawings by C. Besuchet). Scale bar: $0.1 \mathrm{~mm}$. 
Description: Body length $1.2-1.3 \mathrm{~mm}$. Habitus as in Fig. 4. Colouration: body reddish to brown, sometimes with the elytra somewhat darker than the head and pronotum. Eyes composed of 5-10 ommatidia. Other external characters as in C. fractum.

$\sigma^{*}$ : protibia distinctly bent subapically and excavated in subapical portion, apically dilated; metaventrite shallowly and extensively impressed; aedeagus (Figs 33, 47) long and slender, $0.55-0.58 \mathrm{~mm}$ long; ventral process not constricted, subapically abruptly narrowed, and apically with long median extension; internal sac with weakly sclerotized small structures; paramere long and straight, each with a long and curved apical seta.

Comparative notes: This species is distinguished from the similar C. fractum especially by a shorter aedeagus with a ventral process of different shape and with a longer apical median extension. In addition, the male metaventrite is shallowly impressed and the colouration is on average paler.

Distribution and natural history: The type locality is situated in the south slopes of Uludağ, Bursa (Map 1). The specimens were sifted from litter in a grassy valley surrounded by pine forest at an altitude of $1200 \mathrm{~m}$.

\section{Cephennium immutatum spec. nov. urn:Isid:zoobank.org:act:F24C0315-7B6F-427E-B9AB-65AB304F7718 (Figs 5, 34-35, Map 1)}

Type material examined: Holotype $0^{\top}:$ "N37"26'35 E028 $18^{\prime} 07$ (4), Türkei Mugla Yatagan, Bozdogan $825 \mathrm{~m}$ 19.4.2006, 1. Brachat \& Meybohm / Holotypus o Cephennium immutatum sp. n., det. V. Assing 2020" (cAss). Paratypes: 1 \%: “N37²8'39 E027²8'41 Türkei Mugla (1), Bafa See Südküste, 1. J. Martens 22.3.2006” (cAss); 1 ơ: "N38²4'19 E02723'31 (17), Türkei Izmir Nif Dagi, 970 m 24.4.2006, 1. Brachat \& Meybohm" (cAss); 1 o $^{*}$ : “TR Adiyaman [22], $50 \mathrm{~km}$ NE Adıyaman, 8 km NE Narince, $870 \mathrm{~m}, 37^{\circ} 54^{\prime} 58 \mathrm{~N}, 38^{\circ} 48^{\prime} 45 \mathrm{E}, 24$. III.2005, P. Wunderle" (cAss).

Etymology: The specific epithet (Latin, adjective: unchanged) alludes to the nearly unmodified male protibiae, one of the characters distinguishing this species from C. bodemeyeri.

Description: Body length $1.20-1.25 \mathrm{~mm}$; length of pronotum $0.4 \mathrm{~mm}$; width of pronotum $0.47-0.50 \mathrm{~mm}$; length of antennae approximately $0.55 \mathrm{~mm}$. Habitus as in Fig. 5. Colouration: body dark-brown.

Eyes composed of approximately ten ommatidia. Antenna with pronounced club formed by antennomeres IX-XI; antennomere VIII slightly smaller than antennomere VII and much smaller than antennomere IX; antennomere XII less than twice as long as broad.
Pronotum 1.18-1.25 times as broad as long, broadest in anterior half, and moderately convex in cross-section; lateral margins straight in posterior half.

Elytra each anteriorly with a subcircular to transversely oval impression with long and tomentose whitish pubescence; humeral carina fine, approximately as long as the combined length of the basal 2-3 antennomeres.

$0^{*}$ : protibia nearly unmodified, very weakly curved subapically; aedeagus (Figs 34-35) approximately $0.38 \mathrm{~mm}$ long; ventral process apically with a short median extension in ventral view; internal sac with a pair of weakly sclerotized small structures and basally with a broad membranous structure; paramere weakly sinuate subapically, far from reaching apex of ventral process, and apically with a moderately long seta.

Comparative notes: This species is distinguished from C. bodemeyeri by slightly smaller size, more slender elytra with less transverse basal impressions, nearly unmodified male protibiae, and a much smaller aedeagus of different shape.

Distribution and natural history: The distribution extends from Izmir and Muğla in the West and Southwest Anatolia eastwards to Adryaman (Map 1). The specimens were sifted on a rocky north slope with oak, near rocks, and in a stream valley with Platanus and Crataegus. The altitudes range from near sea-level to $970 \mathrm{~m}$. The female paratype (collected in March) appears to be teneral.

\section{Cephennium ericinum group}

Species of intermediate to relatively large size; body length 1.3-1.7 mm. Body of reddish to dark-brown colouration. Eyes reduced to minute rudiments without ommatidia and pigmentation (Figs 7-8). Pronotum large in relation to elytra (e.g., Figs 6, 9), approximately as broad as elytra. Elytra without tomentose impressions anteriorly; humeral carina distinct, approximately as long as the combined length of the basal 3-4 antennomeres.

$\sigma^{\star}$ : protibia subapically not, or only weakly curved, flattened to weakly excavate in apical third to apical half; metaventrite extensively and rather deeply impressed; aedeagus with ventral process more or less gradually narrowed apicad, apically of more or less triangular shape; internal sac with spine-shaped structures of speciesspecific shapes and arrangement; parameres relatively short, thin, and non-sinuate, apically (seta excluded) extending to apical fourth or third of ventral process, with short and indistinct apical seta.

Species of the C. ericinum group are locally endemic in the region from Zonguldak province in the west to Ordu province in the east, Northwest and North Anatolia (Map 2). 
Cephennium ericinum spec. nov. urn:Isid:zoobank.org:act:F56474A9-C330-4019-BD58-B566E66CF58E

(Figs 6-7, 36-37, Map 2)

Type material examined: Holotype ơ: “TR [22] Ordu, $15 \mathrm{~km} \mathrm{~S} \mathrm{Ordu,} \mathrm{S} \mathrm{Kabaduz,} 990 \mathrm{~m}$, mixed forest, $40^{\circ} 48^{\prime} 59 \mathrm{~N}, 37^{\circ} 54^{\prime} 28 \mathrm{E}, 30$.VII.2006, M. Schülke / Holotypus o Cephennium ericinum sp. n., det. V. Assing 2020" (cAss). Paratypes: $2 \sigma^{\star} \sigma^{\star}$ [one with aedeagus lost], 3 우 9 : same data as holotype (cAss, MNB).

Etymology: The specific epithet is an adjective derived from the Latin noun ericius (hedgehog) and alludes to the spinose internal structures of the aedeagus.

Description: Rather large species; body length $1.6-1.8 \mathrm{~mm}$; length of pronotum $0.47-0.53 \mathrm{~mm}$; width of pronotum $0.60-0.67 \mathrm{~mm}$; length of antennae approximately $0.7 \mathrm{~mm}$. Habitus as in Fig. 6. Colouration: body dark-reddish to dark-brown.

Eyes reduced to minute rudiments without ommatidia (Fig. 7). Pronotum approximately 1.25 times as broad as long, broadest in anterior half, and strongly convex in cross-section; lateral margins straight in posterior half. Elytra without tomentose impressions anteriorly; humeral carinae distinct, approximately as long as the combined length of the basal 3-4 antennomeres.

$\sigma^{*}$ : protibia subapically curved and somewhat excavate and flattened on inner side; aedeagus (Figs 36-37) 0.44-0.45 mm long; ventral process gradually narrowed apicad, of acutely triangular shape in ventral view; internal sac with long, weakly sclerotized, and apically spinose structures; parameres short and thin, not sinuate, apically extending approximately to middle of ventral process, and with rather short and thin apical seta.
Comparative notes: Cephennium ericinum is readily distinguished from other congeners known from Turkey by larger body size alone. It is additionally characterized by strongly reduced eyes, the absence of tomentose anterior impressions on the elytra, and the morphology of the aedeagus.

Distribution and natural history: The type locality is situated to the south of Ordu, Ordu province, North Anatolia (Map 2). The specimens were sifted from leaf litter in a mixed forest with alder, spruce, bramble, and ivy at an altitude of $990 \mathrm{~m}$.

\section{Cephennium varispinosum spec. nov.}

urn:Isid:zoobank.org:act:04C4304D-F84A-400B-8710-15407DE9BCCD

(Figs 8-9, 38-39, Map 2)

Type material examined: Holotype $\sigma^{*}$ : "TR [11] Ordu, $18 \mathrm{~km}$ NE Akkuş, 4056'03"[N], 3706'47"[E], $920 \mathrm{~m}$, mixed deciduous forest, 15.VII.2008, V. Assing / Holotypus o Cephennium varispinosum sp. n., det. V. Assing 2020" (cAss). Paratype $0^{\top}$ : same data as holotype (cAss).

Etymology: The specific epithet is an adjective composed of the adjective varius (various) and spinosum (spinose). It alludes to the presence of spines of various sizes and shapes in the internal sac of the aedeagus.

Description: Body length $1.4-1.5 \mathrm{~mm}$; length of pronotum $0.45 \mathrm{~mm}$; width of pronotum $0.54 \mathrm{~mm}$; length of antennae approximately $0.6 \mathrm{~mm}$. Habitus as in Fig. 9. Colouration: forebody reddish-brown; elytra reddish.

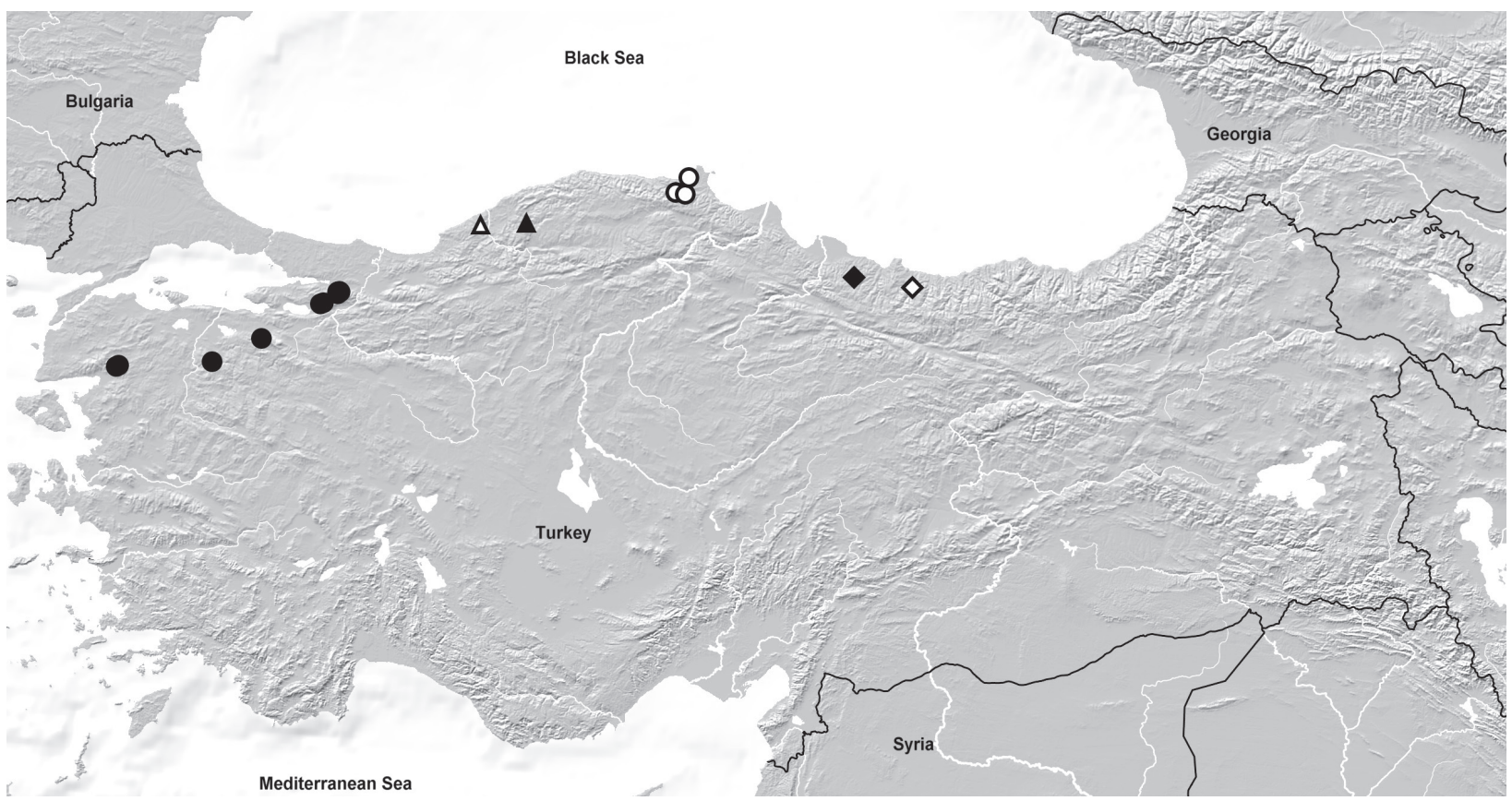

Map 2: Distributions of Cephennium fractum (black circles) and of the species of the C. ericinum group: C. digitale (white triangle); C. spinigerum (black triangle); C. victrix (white circles); C. varispinosum (black diamond); C. ericinum (white diamond). 
Eyes reduced to small rudiments without ommatidia (Fig. 8). Antennomeres VIII-X strongly transverse. Pronotum rather large in relation to elytra and as broad as elytra, 1.2 times as broad as long, broadest in anterior half, and strongly convex in cross-section; lateral margins straight in posterior half. Elytra without tomentose impressions anteriorly; humeral carina distinct, approximately as long as the combined length of the basal 3-4 antennomeres.

$\sigma^{\top}$ : protibia subapically not curved, but somewhat flattened on inner side; aedeagus (Figs 38-39) 0.38 mm long; ventral process gradually narrowed apicad in ventral view; internal sac with approximately eight weakly sclerotized and rather small spines of various sizes and shapes ventrally, and with a pair of larger and strongly curved spines dorsally; parameres very thin and indistinct, not sinuate, extending to apical third of ventral process.

Comparative notes: Aside from its aedeagus, C. varispinosum is characterized among the Turkish Cephennium species by a rather large pronotum, strongly reduced eyes, and strongly transverse antennomeres VIII-X. It is additionally separated from the geographically close C. ericinum by much smaller size and weakly modified male protibiae.

Distribution and natural history: The type locality is situated to the northeast of Akkuş, Ordu province, North Anatolia (Map 2). The specimens were sifted from leaf litter in a mixed forest with predominant Fagus at an altitude of $620 \mathrm{~m}$.

\section{Cephennium victrix spec. nov. urn:Isid:zoobank.org:act:2BC2443C-70A2-4B5B-874A-FAF0F4DCFB62 (Figs 10, 40-41, Map 2)}

Type material examined: Holotype ơ: “TR [15] - Sinop,

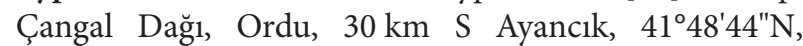
34³9'19"E, 920 m, beech forest, 1.IV.2009, V. Assing / Holotypus o Cephennium victrix sp. n., det. V. Assing 2020" (cAss). Paratypes: $1 \sigma^{\star}, 2$ ㅇ 우 : same data as holotype (cAss); 3 ơ o , 6 ㅇ ㅇ : “TR [16] - Sinop, Çangal Dağ 1 , Ordu,

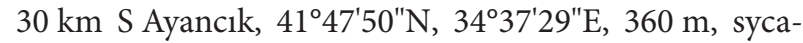
more forest, 1.IV.2009, V. Assing” (cAss); 1 o : “TR [20]

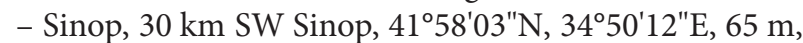
mixed deciduous forest, 2.IV.2009, V. Assing" (cAss).

Etymology: The specific epithet (Latin, adjective: winning) alludes to the shape of the median pair of internal structures of the aedeagus, which together form a " $V$ " (as in victory).

Description: Body length $1.3-1.4 \mathrm{~mm}$. Habitus as in Fig. 10. Colouration: body reddish to reddish-brown with the elytra often slightly paler than head and pronotum. Antennae with antennomeres VIII-X moderately transverse, other external characters as in C. varispinosum. o: protibia subapically not curved, but somewhat flattened on inner side in apical portion; aedeagus (Figs 40-41) 0.33-0.35 mm long; ventral process subapically abruptly narrowed and apically acute in ventral view; internal sac with a pair of lateral clusters of small weakly sclerotized spines and with a median pair of longer weakly sclerotized spines forming a "V"; parameres thin, not sinuate, extending to apical fourth of ventral process.

Comparative notes: Cephennium victrix is reliably distinguished from the similar C. varispinosum especially by a smaller aedeagus with a ventral process and internal structures of different shapes and arrangement, respectively, additionally also by less transverse antennomeres VIII-X.

Distribution and natural history: The specimens were collected in three localities in Sinop province, North Turkey, by sifting leaf litter in a beech forest, in a moist sycamore forest with rocks, and in a mixed deciduous forest with hornbeam, oak, and laurel at altitudes of 65-920 m.

\section{Cephennium spinigerum spec. nov. urn:Isid:zoobank.org:act:7321FC90-18ED-4F50-8CFA-58F338EA62BB}

Type material examined: Holotype $0^{\star}$ : "N41 $28^{\circ} 08$ E32³5'52 (21), TR Bartin 30.4.2014, Bahcedik $3 \mathrm{~km} \mathrm{~s}$ 510 m, Brachat \& Meybohm / Holotypus ơ Cephennium spinigerum sp. n., det. V. Assing 2020" (cAss).

Etymology: The specific epithet (Latin, adjective: spinose) alludes to the numerous spines in the internal sac of the aedeagus.

Description: Body length $1.4 \mathrm{~mm}$. Habitus as in Fig. 11. Colouration: body dark-reddish. Antennae with antennomeres VIII-X moderately transverse, other external characters as in C. varispinosum.

$\sigma^{\star}$ : protibia subapically not curved, but somewhat flattened on inner side in apical portion; aedeagus (Figs 42-43) $0.38 \mathrm{~mm}$ long; ventral process apically of triangular shape in ventral view; internal sac with numerous rather stout spines; parameres thin, not sinuate, extending to apical third of ventral process.

Comparative notes: This species is distinguished from the similar and geographically close $C$. victrix only by the shape and internal structures of the aedeagus.

Distribution and natural history: The type locality is situated in Bartin province, Northwest Anatolia (Map 2). The holotype was sifted from litter near old trees in a beech forest with rhododendron undergrowth at an altitude of $510 \mathrm{~m}$. 
Cephennium digitale spec. nov. urn:Isid:zoobank.org:act:06ED0DE9-D72E-410C-9A7A-B7330175D3D9

(Figs 12, 44-45, Map 2)

Type material examined: Holotype $0^{\top}$ : “N41²5'53 E31 ${ }^{\circ} 57^{\prime} 51$ (24), TR Zonguldak 1.5.2014, Caycuma w $570 \mathrm{~m}$, Brachat \& Meybohm / Holotypus ơ Cephennium digitale sp. n., det. V. Assing 2020" (cAss).

Etymology: The specific epithet (Latin, adjective: of a/the finger) alludes to the finger-shaped spines in the internal sac of the aedeagus.

Description: Body length $1.4 \mathrm{~mm}$. Habitus as in Fig. 12 . Colouration: body dark-reddish. External characters as in C. spinigerum.

$0^{7}$ : protibia subapically not curved, weakly excavate in apical portion; aedeagus (Figs 44-45) $0.39 \mathrm{~mm}$ long; apex of ventral process of narrowly triangular shape in ventral view; internal sac with several horn- or fingershaped structures of various sizes and shapes; parameres thin, not sinuate, extending to apical third of ventral process.

Comparative notes: Cephennium digitale differs from the similar and geographically close C. spinigerum only by a more slender aedeagus with fewer internal spines of different shapes.

Distribution and natural history: The type locality is situated in Zonguldak province, Northwest Anatolia (Map 2). The holotype was sifted from litter in a beech forest with rhododendron undergrowth at an altitude of $570 \mathrm{~m}$.

\section{Cephennium jonicum group}

Species of small size (1.0-1.1 mm), slender habitus, relatively long elytra, and pale-reddish colouration. Eyes composed of approximately five defined ommatidia without, or with weak, pigmentation. Punctation of pronotum at least slightly more distinct than that of elytra. Elytra each with a small impression with whitish tomentose pubescence anteriorly. Hind wings completely reduced. $\sigma^{\star}$ : protibia without distinct modifications; metaventrite extensively depressed or impressed; aedeagus (e.g., Figs 48-50) with bulbous capsule, basally subcircular in cross-section, approximately twice as long as broad; internal structures minute; parameres thin, apically extending slightly beyond apex of median lobe, with short and fine apical seta.

The C. jonicum group includes several described and undescribed species distributed in the Balkans. In the study region, the $C$. jonicum group is represented by only a single species, C. reductum, which has been recorded from both the Taurus and the Pontic Mountains (South and North Anatolia) (Map 3).
Cephennium reductum spec. nov.

urn:Isid:zoobank.org:act:CB292C96-5EC1-4947-AEOF-3D3F3094C77A

(Figs 13, 48-50, Map 3)

Type material: Holotype $0^{\star}$ : “TR Mersin (48), Güzeloluk-Erdemli, S Aydinlar 1350 m / (48) 7.5.2004, leg. Brachat \& Meybohm, 3644'59N 34 $4^{\circ} 7^{\prime} 48 \mathrm{E} /$ Holotypus o Cephennium reductum sp. n., det. V. Assing 2020" (cAss). Paratypes: $10^{*}$ : “TR Mersin (46), Kirobasi-Güzeloluk, 14 km W Güz. 1430 m / 36²45'1N $33^{\circ} 57^{\prime} 51 \mathrm{E}$ (46) 8.5.2004, leg. Brachat \& Meybohm" (cAss); 1 o $^{\star}, 1$ ㅇ: “N3752' E03120', Türkei Umg. Beysehir, Gedikli 7 km s. 1000 m, Meybohm 14.5.2000” (cAss); 1 o', 1 ㅇ: "N36² $26^{\prime} \mathrm{E} 032^{\circ} 53^{\prime}$, Türkei nördl. Anamur, Ermenek Umg. 1450 m, Meybohm 20.5.2000” (cAss); 1 ㅇ: "N362 $21^{\prime}$ E032 56 ', Türkei Umg. Anamur, Abanoz 1240 m, Meybohm 19.5.2000” (cAss); 1 ㅇ: “N36²44'01 E3351'16, Türkei Mersin (8), Kirobasi 1390 m, 1 km w. Kirobasi / Ku[1]turland am Bach, 19.4.2005 (8), leg. Brachat \& Meybohm” (cAss); 1 \%: “TR Mersin (41), road Mut-Karaman, Sertavul Gec. 1570 m / 36 $55^{\circ} 28 \mathrm{~N}$ $33^{\circ} 16^{\prime} 26 \mathrm{E}$ (41), 5.5.2004, leg. Brachat \& Meybohm" (cAss); $10^{*}:$ "TR [36a] - Kastamonu, 40 km NW Kastamonu, 41 $42^{\prime} 05^{\prime \prime} \mathrm{N}, 33^{\circ} 28^{\prime} 17^{\prime \prime} \mathrm{E}, 1090 \mathrm{~m}$, calcareous slope, 9.IV.2009, V. Assing" (cAss).

Etymology: The specific epithet (Latin, adjective) alludes to the conspicuously small internal structures of the aedeagus.

Description: In external characters similar to species of the C.corruptum group (see below). Body length 1.0-1.1 mm. Habitus slender (Fig. 13). Eyes composed of approximately five defined ommatidia without pigmentation. Punctation of pronotum slightly to distinctly less fine than that of elytra. Elytra each with a small obliquely oval impression with whitish tomentose pubescence anteriorly. Hind wings completely reduced.

$o^{*}$ : protibia unmodified; metaventrite extensively triangularly depressed (not impressed); aedeagus (Figs 48-50) 0.27-0.29 mm long, approximately twice as long as broad in ventral view; capsule bulbous, basally subcircular in cross-section; ventral process apically moderately broadly truncate and in the middle with small projection in ventral view; internal sac with two very small apico-median structures; paramere apically extending slightly beyond apex of median lobe, with short apical seta.

Comparative notes: This species is distinguished from the externally similar representatives of the C.corruptum group by a more oblong aedeagus with a bulbous capsule (not strongly depressed dorso-ventrally), with a more slender and apically less broadly truncate ventral process, and with smaller internal structures of different shapes and arrangement, from the geographically close C. corruptum also by more distinct punctation of the pronotum. It differs from other described and 
undescribed species of the C. jonicum group, which are distributed in the Balkans, primarily by the shapes of the internal structures (especially the apical structure) of the aedeagus, from most of them also by a smaller aedeagus.

Distribution and natural history: Unlike the externally similar species of the C. corruptum group (see below),
C. reductum is not locally endemic, but distributed in both the Pontic (Kastamonu) and the Taurus Mountains (Konya, Antalya, Mersin) (Map 3). The specimens were sifted from grass and moss in a calcareous slope and from litter of Crataegus and Berberis (partly near rocks). The altitudes range from 1000 to $1570 \mathrm{~m}$.

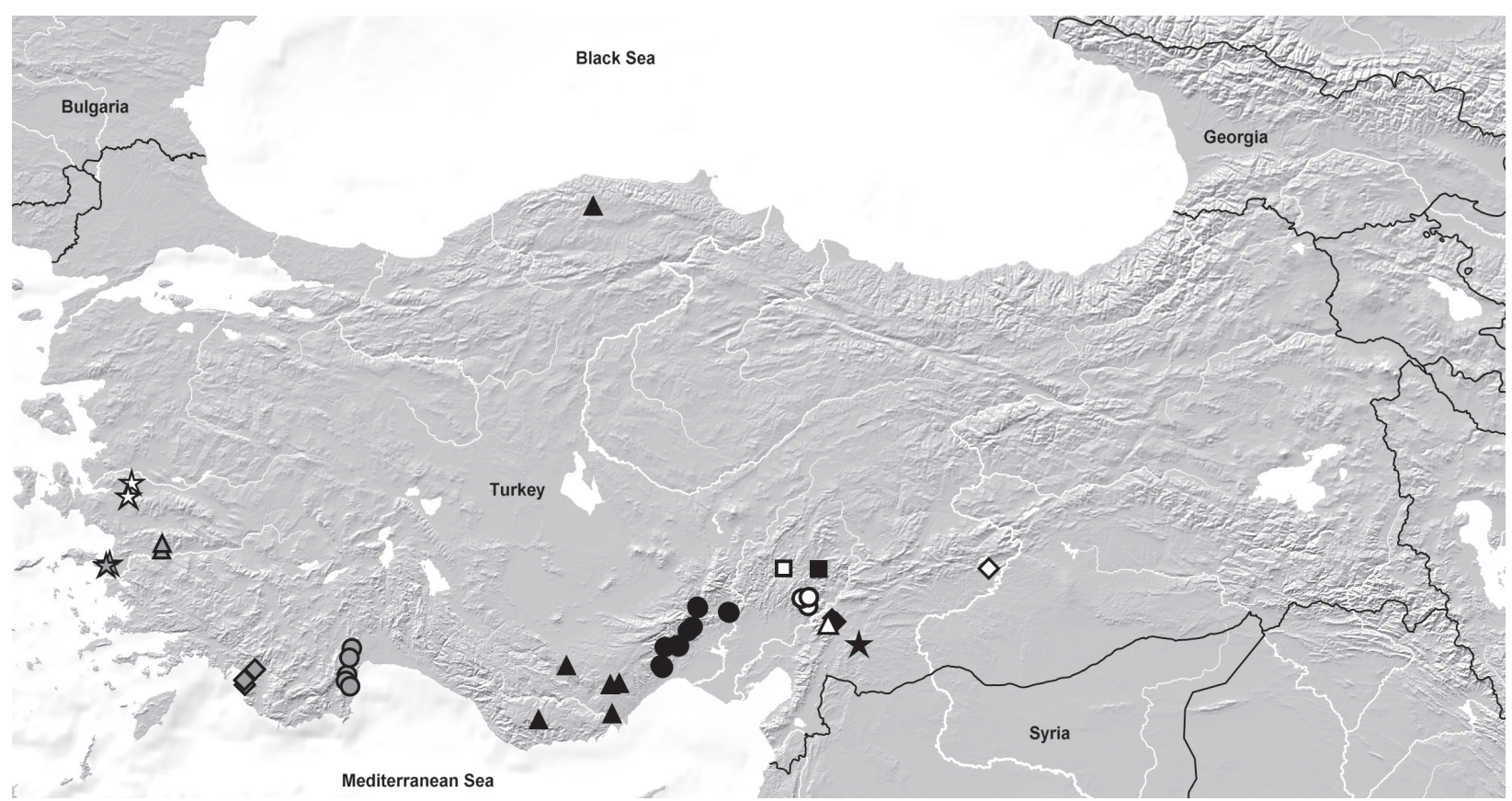

Map 3: Distributions of the species of the Cephennium jonicum and C. corruptum groups in Turkey: C. unguicum (grey stars); C. deplectens (white stars); C. sicaferum (grey triangles); C. duplum (grey diamonds); C. geminum (grey circles); C. reductum (black triangles); C. corruptum (black circles); C. fimbriatum (white square); C. besucheti (black square); C. affimbriatum (white circles); C. marasicum (black diamonds); C. dolucanum (white triangle); C. kartalicum (black star); C. nemruticum (white diamond).

\section{Cephennium corruptum group}

Species of small size $(0.9-1.2 \mathrm{~mm})$, slender habitus, relatively long elytra, and pale colouration (usually reddish-yellow). Eyes composed of 3-5, sometimes weakly defined ommatidia without, or with very weak, pigmentation. Punctation of pronotum often more distinct than that of elytra. Elytra each with a small circular or transversely oval impression with whitish tomentose pubescence anteriorly. Hind wings completely reduced.

$o^{\top}$ : protibia without distinct modifications; metaventrite extensively and shallowly impressed, depressed, or unmodified; aedeagus strongly dorso-ventrally depressed and short, much less than twice as long as broad; ventral process short and broad, apically broadly truncate; internal structures weakly to moderately sclerotized, not conspicuously minute, apico-medially with a more or less transverse structure; parameres thin, apically extending to, nearly to, or beyond apex of median lobe, with short and fine apical seta.

The species of the C. corruptum group can be assigned to two subgroups, one of them (C. unguicum subgroup) including five species (C. unguicum, C. deplectens,
C. sicaferum, C. geminum, C. duplum) from Southwest Anatolia and characterized by the presence of pairs of large spines in the internal sac of the aedeagus. The C. corruptum subgroup, which comprises the remaining ten species, is distributed in central southern Anatolia, Lebanon, and Jordan and lacks such distinct spines.

In the study region, the representatives of the C. corruptum group are locally endemic in South and Southwest Turkey (thirteen species), Lebanon (one), and Jordan (one) (Map 3).

\section{Cephennium corruptum subgroup}

\section{Cephennium corruptum spec. nov. urn:Isid:zoobank.org:act:BC5C6DE3-2696-4949-B84F-E7336C5DC774 (Figs 14, 57, Map 3)}

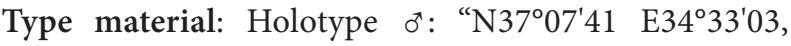
Türkei Mersin (25/26), Camliyayla, 3 km w. Sebil 1060$1090 \mathrm{~m} /$ Streu an Felsen, 24.4.2005 (25/26), leg. Brachat \& Meybohm / Holotypus o Cephennium corruptum sp. n., det. V. Assing 2020" (cAss). Paratypes: $8 \sigma^{\star \top} \sigma^{\text {त, }}$ 1 옹 same data as holotype (cAss); $1 o^{\star}:$ “TR - Mersin, 
ca. $30 \mathrm{~km}$ NNW Tarsus, $430 \mathrm{~m}$, No. 7, 370' $43 \mathrm{~N}$, $34^{\circ} 44^{\prime} 29 \mathrm{E}$, Pinus, Q. ilex, Juglans, 26.12.2000, V. Assing” (cAss); $10^{\star}$ : “TR Umg. Mersin, Mersin - Arslanköy, 9 km sö Akdag, N365 55' E34³2' / Süd-Türkei, 6.5.2002, leg. Brachat \& Meybohm” (cAss); 1 잉 “TR Mersin (33), road to Arslanköy, $5 \mathrm{~km}$ SE Aladag $700 \mathrm{~m} / 36^{\circ} 54^{\prime} 45 \mathrm{~N}$ 34³1'44E (33), 2.5.2004, leg. Brachat \& Meybohm" (cAss); 1 \%: “TR Mersin (34), road to Arslanköy,

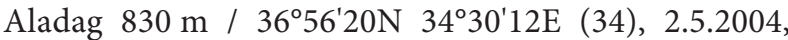
leg. Brachat \& Meybohm" (cAss); 2 o $^{\top} \mathrm{o}^{*}$ : “N37 $08^{\prime} 50$ E034 $42^{\prime} 49$, TR Mersin Daripinari $710 \mathrm{~m}$, E Camliyayla 25.4.2011, Brachat \& Meybohm (28)" (cAss); $2 \sigma^{*} \sigma^{*}$ : “TR Umg. Adana, Ciftehan Tal - Camlyayla [sic] $430 \mathrm{~m}, \mathrm{~N} 37^{\circ} 8^{\prime}, \mathrm{E} 34^{\circ} 44^{\prime}$ / Süd-Türkei, 5.5.2002, leg. Brachat \& Meybohm" (cAss); $20^{\top} o^{\star}:$ "N37²9'34 E352'ㄷㄴ, Türkei Adana (37), Karsanti $910 \mathrm{~m}$ (w Kozan), Hasandede Gec. / Hang mit Seidelbast, 28.4.2005 (37), leg. Brachat \& Meybohm" (cAss); $10^{7}$, 1 우 : N37²9'52 E35²2'48, Türkei Adana (38), Karsanti 1100 m (w Kozan), w Hasandede Gec. / Tannenwald, 28.4.2005 (38), leg. Brachat \& Meybohm" (cAss); 1 ㅇ: "N3720'33 E034 54'41, TR Adana Belemedik, 710 m, 15.4.2011, Brachat \& Meybohm (2)" (cAss); $10^{\star}, 1$ 우 “N37³2'30 E03458'55, TR Adana Kamisli E $5 \mathrm{~km}$ 1450 m, 24.4.2011, Brachat \& Meybohm (30)" (cAss); 2 o $^{\star}$ o $^{\star}, 1$ i : “N37³3'00 E03458'36, TR Adana Kamisli E $4 \mathrm{~km} 1385 \mathrm{~m}, 26.4 .2011$, Brachat \& Meybohm (31)" (cAss); 1 ㅇ: “TR Umg. Adana, südl. Pozanti, Tekir, 1200-1400 m, N37º18', E3451' / Süd-Türkei, 4.5.2002, leg. Brachat \& Meybohm" (cAss).

Etymology: The specific epithet is the past participle of the Latin verb corrumpere (to decay) and alludes to the fungus-shaped internal structures of the aedeagus.

Description: Body length $1.0-1.2 \mathrm{~mm}$; length of pronotum $0.30-0.35 \mathrm{~mm}$; width of pronotum $0.40-0.44 \mathrm{~mm}$; length of antennae $0.45-0.50 \mathrm{~mm}$. Habitus as in Fig. 14 . Colouration: body yellowish-red.

Eyes composed of approximately five ommatidia. Antenna with antennomeres VIII-X moderately transverse.

Pronotum 1.20-1.25 times as broad as long, broadest in anterior half, and moderately convex in cross-section; lateral margins straight in posterior half; punctation as fine as that of elytra.

Elytra noticeably broader than pronotum, anteriorly with small transversely oval impression with tomentose whitish pubescence; humeral carina pronounced, approximately as long as the combined length of the basal four antennomeres, inner margin of this carina sharply delimited.

$0^{\top}$ : protibia unmodified; metaventrite depressed or shallowly impressed; aedeagus (Fig. 57) short, broad, and apically truncate, approximately $0.25 \mathrm{~mm}$ long; internal sac with structures of distinctive shapes; paramere apically extending nearly to apex of median lobe, with short apical seta.
Comparative notes: Among other species of this group, C. corruptum is reliably identified only based on the shape and the internal structures of the aedeagus.

Distribution and natural history: The distribution includes several localities in Mersin and Adana provinces, central South Anatolia (Map 3). The specimens were sifted in various forested (Pinus, Juglans, Quercus ilex, Cedrus, Juniperus, etc.) and unforested habitats (grassy slopes) or found under stones at altitudes of 430-1450 m.

\section{Cephennium marasicum spec. nov.}

\section{urn:Isid:zoobank.org:act:02420408-99DB-49FA-8A5B-409528E5613A} (Figs 15, 52, Map 3)

Type material: Holotype $0^{\star}:$ 'N $37^{\circ} 23^{\prime} 45$ E036 $48^{\prime} 05$, TR Kahramanmaras, Uzunsögut 660 m (47), 30 km ssw K. Maras / Laubstreu, 4.5.2005, leg. Brachat \& Meybohm / Holotypus o Cephennium marasicum sp. n., det.

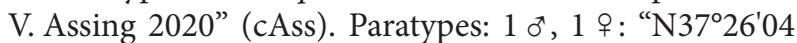
E036 $44^{\prime} 32$ (8), TR Kahramanmaras, 25 km sw Maras, Yesilyöre 800 m, Brachat \& Meybohm 23.4.2007” (cAss).

Etymology: The specific epithet is an adjective derived from Maras, alluding to the fact that the type locality is situated in the Turkish province Kahramanmaraş.

Description: Habitus as in Fig. 15. Punctation of pronotum more distinct than that of elytra. Other external and male secondary sexual characters as in C. corruptum.

$\sigma^{\star}$ : aedeagus (Fig. 52) short, broad, and apically truncate, $0.33 \mathrm{~mm}$ long; internal sac with structures of distinctive shape; paramere apically extending beyong apex of median lobe, with short apical seta.

Comparative notes: Cephennium marasicum is distinguished from the externally similar and geographically close C. corruptum only by relatively more distinct punctation of the pronotum, as well as by the internal structures and longer parameres of the larger aedeagus.

Distribution and natural history: This species is currently known from only two localities to the southwest of Kahramanmaraş, Kahramanmaraş province, central southern Anatolia (Map 3). The specimens were sifted from leaf litter near rocks at altitudes of 660 and $800 \mathrm{~m}$.

\section{Cephennium dolucanum spec. nov. urn:Isid:zoobank.org:act:F0BFE9A7-0AE9-40D2-BC5E-49DE875B2A65 (Figs 16, 53, Map 3)}

Type material: Holotype $\sigma^{\star}$ : “N3723'10 E36 $40^{\circ} 51$, TR Kahramanmaras, Doluca 1040 m (49), $40 \mathrm{~km}$ ssw K. Maras / Steine, Büsche, 4.5.2005 (49), leg. Brachat \& 
Meybohm / Holotypus ot Cephennium dolucanum sp. n., det. V. Assing 2020" (cAss). Paratypes: 1 : : same data as

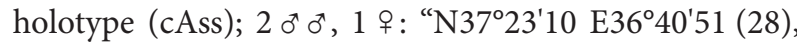
TR Kahramanmaras, W Doluca 1040 m, 40 km SSW Maras Brachat \& Meybohm 30.4.2007” (cAss); 2 o $^{\star}$ o $^{\star}, 1$ ㅇ : same data, but “(28a) ... 2.5.2007” (cAss).

Etymology: The specific epithet is an adjective derived from Doluca, the populated place in whose environs the type locality is situated.

Description: Habitus as in Fig. 16. External and male secondary sexual characters as in C. marasicum.

$\sigma^{\top}$ : aedeagus (Fig. 53) short, broad, and apically truncate, $0.32 \mathrm{~mm}$ long; internal sac with structures of distinctive shape; paramere apically extending beyond apex of median lobe, with short apical seta.

Comparative notes: Cephennium dolucanum is distinguished from the externally identical and geographically close C. marasicum only by the internal structures of the aedeagus.

Distribution and natural history: The type locality is situated near Doluca, some $40 \mathrm{~km}$ to the southwest of Kahramanmaraş, Kahramanmaraş province, central southern Anatolia (Map 3). The specimens were found under stones in the transition zone between arable land and a pine forest an altitude of $1040 \mathrm{~m}$.

\section{Cephennium fimbriatum spec. nov.}

urn:Isid:zoobank.org:act:831C051F-751A-4D9C-A9DA-7E2BCAA4D82E

(Figs 17, 58, 70, Map 3)

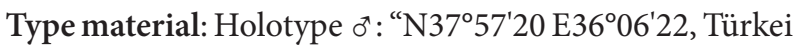
Adana (35/36), Eyüplü 1560 m, s Saimbeyli (n Kozan) / Tannen, Polsterpfl., 27.4.2005 (35/36), Brachat \& Meybohm / Holotypus o Cephennium fimbriatum sp. n., det. V. Assing 2020" (cAss). Paratypes: $5 o^{\star} o^{\star}, 4$ 우 $q$ : same data as holotype (cAss).

Etymology: The specific epithet is an adjective derived from the Latin noun fimbria (fringe) and alludes to the partly fimbriate internal structures of the aedeagus.

Description: Habitus as in Fig. 17. Pronotum with slightly more distinct punctation than elytra. Other external and male secondary sexual characters as in C. marasicum and C. corruptum.

$\sigma^{\top}$ : aedeagus (Fig. 58) short, broad, and apically truncate, approximately $0.27 \mathrm{~mm}$ long; internal sac with partly fimbriate structures of distinctive shape; paramere apically extending beyond apex of median lobe, with short apical seta.

Comparative notes: Cephennium fimbriatum is distinguished from the externally similar C. marasicum and C. dolucanum by finer punctation of the pronotum and especially by the smaller aedeagus with internal structures of different shapes.

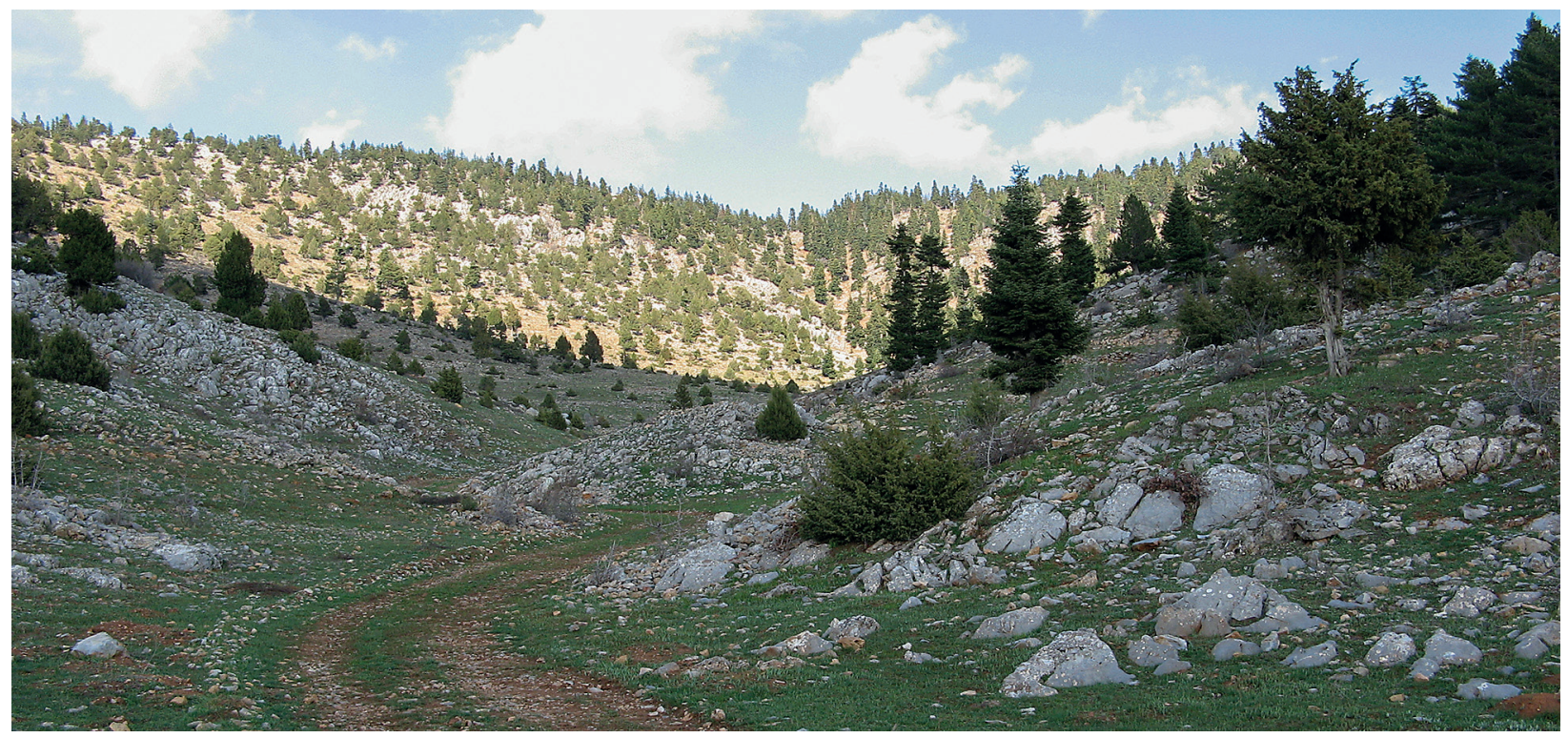

Fig. 70: Type locality of Cephennium fimbriatum (Adana: Eyüplü).

Distribution and natural history: The type locality (Fig. 70) is situated to the north of Kozan, Adana province, central southern Anatolia (Map 3). The specimens were sifted from cushion plants and fir litter at an altitude of $1560 \mathrm{~m}$. 
Cephennium besucheti spec. nov. urn:Isid:zoobank.org:act:A8444FFB-F5BA-4E89-9B50-656496BF5515 (Figs 18, 54, Map 3)

Type material: Holotype $o^{\star}:$ “TR Karahmanmaras [sic] (18) Pass N Tekir S Göksun, 1400-1550 m / 37056'56N $36^{\circ} 34^{\prime} \mathrm{E}$ (18) 26.4.2004, Brachat \& Meybohm / Holotypus $0^{*}$ Cephennium besucheti sp. n., det. V. Assing 2020" (cAss). Paratypes: $2 \sigma^{\star} \sigma^{\star}, 3$ 우 : same data as holotype (cAss).

Etymology: This species is dedicated to our late friend, Claude Besuchet, specialist of Pselaphinae and Scydmaeninae. He studied Cephennium, including the available type material of the described species, in the 1960 s, prepared superb drawings of the aedeagus of both described and numerous undescribed species, but unfortunately never published his results. He also participated in the field trip to Turkey in 2004.

Description: Habitus as in Fig. 18. Pronotum with more distinct punctation than elytra. Other external and male secondary sexual characters as in C. marasicum and C. corruptum.

$0^{*}$ : aedeagus (Fig. 54) short, broad, and apically truncate, approximately $0.33 \mathrm{~mm}$ long; internal sac with narrowly fimbriate structures of distinctive shape; paramere apically extending slightly beyond apex of median lobe, with short apical seta.

Comparative notes: Cephennium besucheti is reliably distinguished from other species of the C.corruptum group only by the shape and internal structures of the aedeagus.

Distribution and natural history: The type locality is situated to the southeast of Göksun in the west of Kahramanmaraş province, central southern Anatolia (Map 3). The specimens were sifted from litter on slopes with cedar, fir, and cypress at an altitude between $1400-1550 \mathrm{~m}$

\section{Cephennium affimbriatum spec. nov.} urn:Isid:zoobank.org:act:02ED0B80-53CF-4ED8-8648-F45DC12696B5 (Figs 19, 55, Map 3)

Type material: Holotype ơ: "N37³9'14 E36²6'27, TR Kahramanmaras, Andirin-Geben, 1500 m, 12,5 km von Andirin (45) / Felswand, Tannen, 3.5.2005 (45), leg. Brachat \& Meybohm / Holotypus o Cephennium affimbriatum sp. n., det. V. Assing 2020" (cAss). Paratypes: $3 \sigma^{\star} \sigma^{\star}, 1$ : : same data as holotype (cAss); $2 \sigma^{\star} \sigma^{*}$ : “N37 33'28 E36 $25^{\circ} 54$, TR Kahramanmaras, Torlar $1110 \mathrm{~m}(41), 18 \mathrm{~km}$ sö Andirin / Streu, Steine (41), 30.4./2.5.2005 (45), leg. Brachat \& Meybohm" (cAss); 3 o $^{\top}$ o $^{\top}$ : "N373' 19 E36 $20^{\circ} 51$, TR Kahramanmaras, Andirin-Cokak $1150 \mathrm{~m}, 10 \mathrm{~km}$ n Andirin (41) / Carpinus,
Quellen, 1./2.5.2005 (43), leg. Brachat \& Meybohm" (cAss); 1 ㅇ: “N3739'14 E36 26'27, TR Kahramanmaras, Andirin 12,5 km NE, S Geben, 1500 m, Brachat \& Meybohm, 27.4.2007” (cAss).

Etymology: The specific epithet (without a fringe) alludes to the absence of fimbriate structures in the internal sac of the aedeagus.

Description: Habitus as in Fig. 19. Punctation of pronotum not more distinct than that of elytra. Other external and male secondary sexual characters as in C. marasicum and C. corruptum.

$\sigma^{\star}$ : aedeagus (Fig. 55) short, broad, and apically truncate, approximately $0.27 \mathrm{~mm}$ long; internal sac with non-fimbriate structures of distinctive shapes; paramere apically extending slightly beyond apex of median lobe, with short apical seta.

Comparative notes: Cephennium affimbriatum is reliably distinguished from other species of the C. corruptum group only by the shape and internal structures of the aedeagus.

Distribution and natural history: The currently known distribution is confined to the environs of Andirin in the west of Kahramanmaraş province, central southern Anatolia (Map 3). The specimens were sifted from litter of fir, hornbeam, cedar, and other plants, partly between rocks, at altitudes of 1110-1500 m.

\section{Cephennium kartalicum spec. nov. urn:Isid:zoobank. org:act:27B66398-BD3C-4C54-9DF8-0918EEEB6C65 (Figs 20, 56, Map 3 )}

Type material: Holotype ơ: “TR Gaziantep (17), Kartal Dag $1200 \mathrm{~m}, \quad W$ Yamacoba / 37 $10^{\prime} \mathrm{N}$ E37 $5^{\circ} \mathrm{E}(17)$ 25.4.2004, leg. Brachat \& Meybohm / Holotypus ơ Cephennium kartalicum sp. n., det. V. Assing 2020" (cAss).

Etymology: The specific epithet is an adjective derived from Kartal, the name of the mountain range where the species was discovered.

Description: Body length $1.0 \mathrm{~mm}$. Habitus as in Fig. 20 . Punctation of pronotum much more distinct than that of elytra. Other external and male secondary sexual characters as in C. marasicum and C. corruptum.

$\sigma^{*}$ : aedeagus (Fig. 56) short, broad, and apically truncate, $0.24 \mathrm{~mm}$ long; internal sac with non-fimbriate structures of distinctive shapes; paramere apically extending slightly beyond apex of median lobe, with short apical seta.

Comparative notes: Cephennium kartalicum is reliably distinguished from other species of the C.corruptum group only by the shape and internal structures of the rather small aedeagus. 
Distribution and natural history: The type locality is situated in Kartal Dağı, Gaziantep province, central southern Anatolia (Map 3). The holotype was sifted at an alitude of $1200 \mathrm{~m}$.

\section{Cephennium nemruticum spec. nov. urn:Isid:zoobank.org:act:643B8783-90BC-4DE2-9DA7-45EFCF67778C (Figs 21, 51, Map 3)}

Type material: Holotype o : “TR - Adiyaman [22], $50 \mathrm{~km} \mathrm{NE}$ Adiyaman, $8 \mathrm{~km}$ NE Narince, $870 \mathrm{~m}$, $37^{\circ} 54^{\prime} 58 \mathrm{~N}, 38^{\circ} 48^{\prime} 45 \mathrm{E}, 24 . \mathrm{III}^{2} 2005$, P. Wunderle / Holotypus o Cephennium nemruticum sp. n., det. V. Assing 2020" (cAss).

Etymology: The specific epithet is an adjective derived from Nemrut, the name of the mountain where the species was discovered.

Description: Body length $1.2 \mathrm{~mm}$. Habitus as in Fig. 21. Punctation of pronotum only slightly more distinct than that of elytra. Eye rudiments very small, composed of approximately 3 weakly defined ommatidia. Other external and male secondary sexual characters as in C. marasicum and C. corruptum.

$\sigma^{\star}$ : aedeagus (Fig. 51) short, broad, and apically truncate, approximately $0.33 \mathrm{~mm}$ long; internal sac with weakly sclerotized non-fimbriate structures of distinctive shapes; paramere apically extending to apex of median lobe, with short apical seta.

Comparative notes: Cephennium nemruticum is reliably distinguished from other species of the C.corruptum group only by the shape and internal structures of the aedeagus.

Distribution and natural history: The type locality is situated in Nemrut Dağ southern Anatolia (Map 3). The holotype was sifted from leaf litter in a rocky slope with oak at an alitude of $870 \mathrm{~m}$.

\section{Cephennium judaeum ReItTer, 1882}

(Figs 68-69)

Cephennium judaeum ReItTer, 1882: 552.

Comment: The original description is based on an unspecified number of syntypes, among them at least one male, from "Libanon: Beirut" (Reitter 1882).

Claude Besuchet (unpublished notes) examined the following material: 1 ㅇ. "Beirut. type. coll. Croissandeau

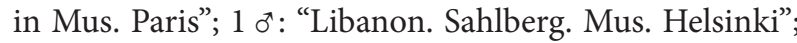
1 9 : "Fleuve Lycus, Liban. Sahlberg. Mus Helsinki"; $1 \mathrm{o}^{*}$ : "Beirut. Appl. coll. mea [now probably in Muséum d'histoire naturelle, Genève]".
Claude Besuchet's drawing of the aedeagus (probably of the male in his collection) is illustrated in Figs 68-69. Based on this drawing, C. judaeum belongs to the C. corruptum group and is most closely allied to the following species. It has been reported only from Lebanon (SCHÜLKe \& SMETANA 2015).

\section{Cephennium jordanicum spec. nov. urn:Isid:zoobank.org:act:900BF391-A399-4559-A132-F1E8F1CFB3E7 (Figs 24, 67, 71)}

Type material: Holotype ơ: "N32 $19^{\prime} 32$ E35²43'26, Jordan Ajlun, Ajlun Castle $980 \mathrm{~m}$ (2), lg. Meybohm 21.2.2014 / Holotypus o Cephennium jordanicum sp. n., det. V. Assing 2020" (cAss).

Etymology: The specific epithet is an adjective derived from Jordan, where this species is at present the sole representative of the genus.

Description: Body length $1.1 \mathrm{~mm}$. Habitus as in Fig. 24 . Punctation of pronotum more distinct than that of elytra. Eyes small, composed of three or four weakly defined ommatidia without pigmentation. Other external and male secondary sexual characters similar to those of other species of the C. corruptum group.

$\sigma^{*}$ : aedeagus (Fig. 67) $0.24 \mathrm{~mm}$ long, broad, and apically truncate; internal sac with two weakly sclerotized apicomedian structures, the lower one fringed with minute spines; paramere apically extending slightly beyond apex of median lobe, with short apical seta.

Comparative notes: Based on the similar shape and internal structures of the aedeagus, C. jordanicum is most closely allied to C.judaeum, from which it is distinguished by the more transverse apical and the more strongly angled subapical internal structure.

Distribution and natural history: The type locality is situated near Ajlun, some $30 \mathrm{~km}$ to the south-southwest of Irbid, Northwest Jordan. The holotype was sifted in a pasture woodland at an altitude of $980 \mathrm{~m}$ (Fig. 71).

\section{Cephennium unguicum subgroup}

\section{Cephennium unguicum spec. nov. urn:Isid:zoobank.org:act:92FD91A3-6A6F-4EBB-BBBF-2CA222D6FD14 (Figs 22, 59, Map 3)}

Type material: Holotype $o^{\star}:$ :N37²41'26 E027 $13^{\prime} 43$ (24), Türkei Aydin Dilek Dagi, s Güzelcamli 410 m 28.4.2006, 1. Brachat \& Meybohm / Holotypus o Cephennium unguicum sp. n., det. V. Assing 2020" (cAss). Paratypes: $30^{\top} \sigma^{\top}$,

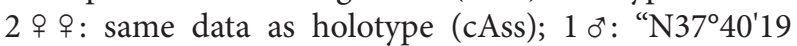
E02710'41 (2), Türkei Aydin Dilek Dagi, s Kanyon 670 m 17.4.2006, 1. Brachat \& Meybohm” (cAss). 


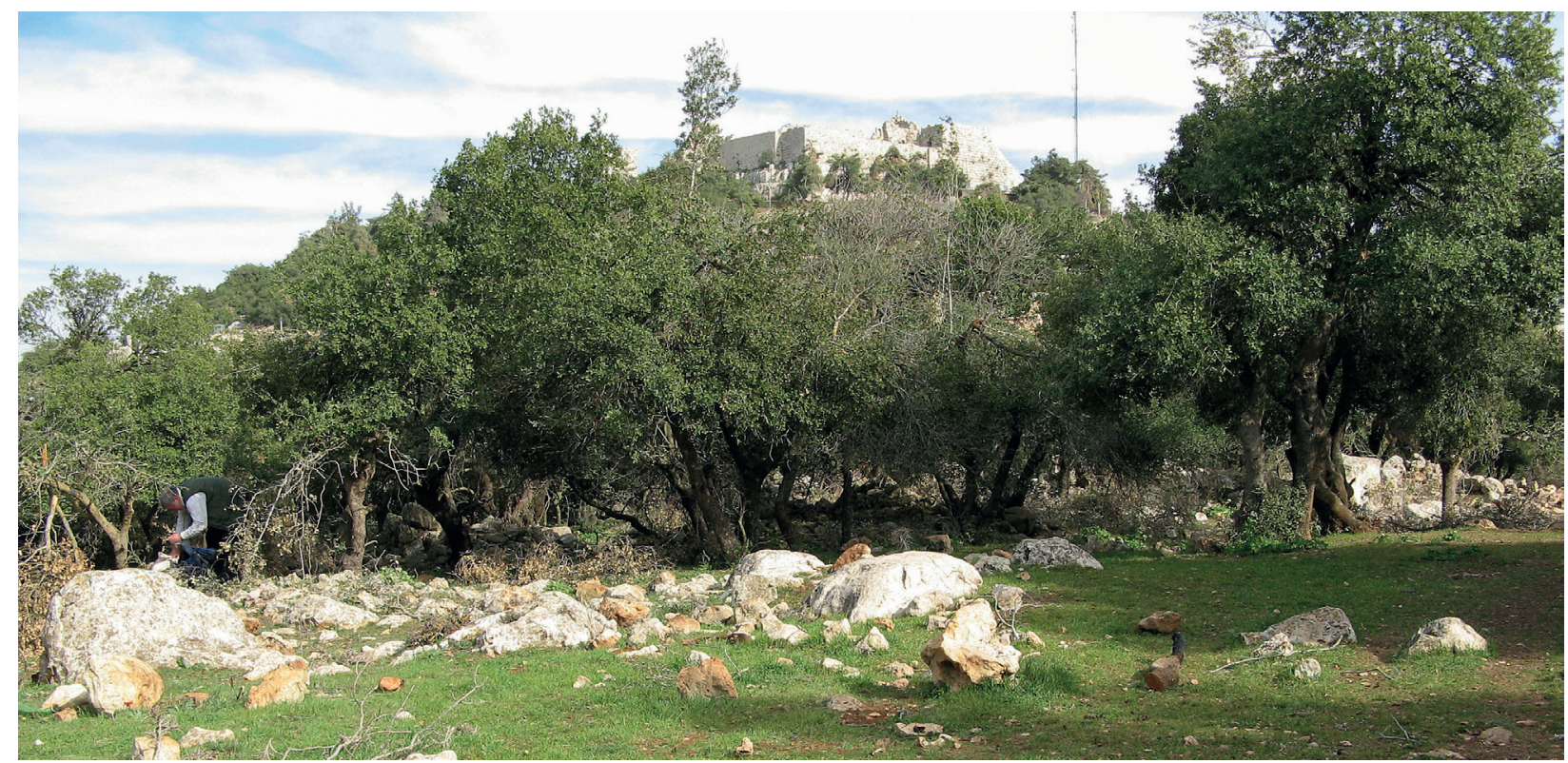

Fig. 71: Type locality of Cephennium jordanicum. Ajlun Castle is visible in the background.

Etymology: The specific epithet is an adjective derived from the Latin noun unguis (claw) and alludes to the conspicuous pair of claw-shaped structures in the internal sac of the aedeagus.

Description: Body length $1.0-1.1 \mathrm{~mm}$. Habitus as in Fig. 22. Punctation of pronotum more distinct than that of elytra. Eye rudiments minute, composed of three or four weakly defined ommatidia without pigmentation. Other external and male secondary sexual characters as in C. marasicum and C. corruptum, except as follows: $\sigma^{\top}$ : metaventrite not impressed, only indistinctly depressed in the middle at most; aedeagus (Fig. 59) small, broad, and apically truncate, $0.23-0.25 \mathrm{~mm}$ long; internal sac with a pair of large and strongly curved claw-shaped structures; paramere apically extending to apex of median lobe, with short apical seta.

Comparative notes: Cephennium unguicum is distinguished from the species of the C.corruptum subgroup by the presence of claw-shaped spines in the internal sac of the aedeagus. For characters separating it from other species of the C. unguicum subgroup see the comparative notes in the following sections.

Distribution and natural history: The type locality is situated in Dilek Dağı (in the peninsula close to the Greek island Samos), Aydın province, Southwest Anatolia (Map 3). The specimens were collected at an altitude of $410 \mathrm{~m}$.

\section{Cephennium sicaferum spec. nov.} urn:Isid:zoobank.org:act:7F1029CB-AD9C-42A6-BBAC-5BDC653EBFEC (Fig. 61, Map 3)

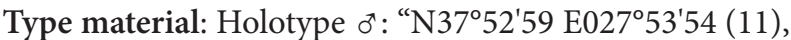
Türkei Aydin Pasayaylasi, 250 m 20.4.2006, l. Brachat \&
Meybohm / Holotypus o Cephennium sicaferum sp. n., det. V. Assing 2020" (cAss). Paratype \%: "N37 $56^{\circ} 47$ E0275'53 (8), Türkei Aydin Pasayaylasi, $1460 \mathrm{~m}$ 20.4.2006, l. Brachat \& Meybohm” (cAss).

Etymology: The specific epithet is an adjective composed of the Latin noun sica (dagger) and the suffix -ferum (carrying). It alludes to the presence of a pair of daggershaped structures in addition to a pair of claw-shaped structures in the internal sac of the aedeagus.

Description: Body length $0.9 \mathrm{~mm}$. Eye rudiments minute, composed of three distinct ommatidia without pigmentation. Other external and male secondary sexual characters as in C. unguicum.

$0^{\top}$ : aedeagus (Fig. 61) of similar shape as in C. unguicum, but smaller, $0.18 \mathrm{~mm}$ long; internal sac with a pair of large and strongly curved claw-shaped structures and additionally with a pair of dagger-shaped structures.

Comparative notes: Cephennium sicaferum is distinguished from the geographically close C. unguicum by slightly smaller body size, eye rudiments composed of three distinct ommatidia, and by a smaller aedeagus with a pair of dagger-shaped structures in addition to a pair of smaller and differently shaped claw-shaped structures. The species differs from the externally similar C. deplectens (see below) only by the longer and more slender dagger-shaped structures and the differently shaped claw-shaped structures in the internal sac.

Distribution and natural history: The type locality is situated near Paşayaylası, Aydın province, Southwest Anatolia (Map 3). The holotype was sifted from litter on a stream bank with Salix and Rubus at an altitude of $250 \mathrm{~m}$, the paratype was found under stones or sifted near stones near a stand of walnut trees at an altude of $1460 \mathrm{~m}$. 
Cephennium deplectens spec. nov. urn:Isid:zoobank.org:act:E16431E9-E6B9-411F-B164-3FA1B7A4D2E2 (Figs 23, 60, Map 3)

Type material: Holotype ơ : “N38²4'19 E027²3'31 (17), Türkei Izmir Nif Dagi, 970 m 24.4.2006, 1. Brachat \& Meybohm / Holotypus ơ Cephennium deplectens sp. n., det. V. Assing 2020" (cAss). Paratypes: $60^{\top} 0^{\top}, 4$ 우 9 : same data as holotype (cAss); $10^{\top}$ : “N38 $24^{\prime} 13 \mathrm{E} 027^{\circ} 23^{\prime} 05$ (18), Türkei Izmir Nif Dagi, $1080 \mathrm{~m}$ 24.4.2006, 1. Brachat \& Meybohm” (cAss); $10^{\circ}$ : “N38³2'51 E027²5'14 (20), Türkei Manisa Sipil Dagi Milli Parki, 1250 m 25.4.2006, 1. Brachat \& Meybohm" (cAss).

Etymology: The specific epithet is the present participle of the Latin verb deplecti (to claw) and alludes to the conspicuous pair of claw-shaped structures in the internal sac of the aedeagus.

Description: Very small species; body length 0.9-1.0 mm. Habitus as in Fig. 23. Punctation of pronotum more distinct than that of elytra. Eye rudiments minute, composed of three or four weakly defined ommatidia without pigmentation. Other external and male secondary sexual characters as in other species of the $C$. unguicum subgroup, except as follows:

$0^{*}$ : metaventrite not impressed, only indistinctly depressed in the middle at most; aedeagus (Fig. 60) very small, broad, and apically truncate, $0.18 \mathrm{~mm}$ long; internal sac with a pair of large and strongly curved claw-shaped structures, with additional pair of straight stout spines, and with a strongly transverse apicomedian structure; paramere apically extending to apex of median lobe, with short apical seta.

Comparative notes: As can be inferred particularly from the similar morphology of the aedeagus (small size; internal sac with pair of claw-shaped structures) and the absence of a median impression on the male metaventrite, $C$. deplectens is evidently closely allied to C. unguicum, from which it is distinguished by smaller body size and particularly by a smaller aedeagus with internal structures of different shapes and arrangement, and to C. sicaferum, from which it differs only by the shapes of the internal structures of the aedeagus (see the comparative notes in the section on C. sicaferum above).

Distribution and natural history: The species was found in two geographically close mountains (Nif Dağı, Sipil Dağı) in Izmir and Manisa provinces, West Anatolia (Map 3). The specimens were sifted from litter near rocks at altitudes of $970-1250 \mathrm{~m}$.

\section{Cephennium geminum spec. nov. urn:Isid:zoobank.org:act:36759AD0-8CA5-44E3-A0A0-D50329D09BOC (Figs 62-64, Map 3)}

Type material: Holotype $0^{\top}$ : “TR-Antalya, Umgeb. Antalya, Termessos, 14.4.1984, leg. V. u. C. Brachat / Holotypus ơ Cephennium geminum sp. n., det. V. Assing 2020" (cAss). Paratypes: $30^{\top} 0^{\top}, 3$ exs.: same data as holotype (cAss); 2 o $^{\top} \sigma^{\top}, 8$ exs.: "N36 $59^{\prime} 23$ E30 $28^{\circ} 6$, TR Antalya Termessos, $880 \mathrm{~m}$ 9.3.1979, leg. Fülscher \& Meybohm" (cAss); 3 o $^{\top}, 1$ ㅇ: "Türkei Umg. Antalya,

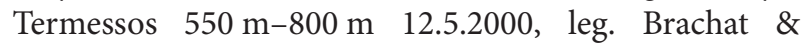

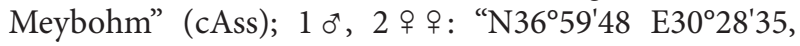
TR Antalya Termessos, $700 \mathrm{~m}$ 21.4.2001, leg. Brachat \&

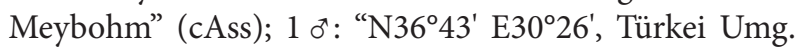
Antalya, südl. Hisar, $1120 \mathrm{~m}$, Meybohm 23.4.2001" (cAss); $10^{\text {*: }}$ "Türkey Umg. Antalya, Straße nach Saklikent, 1000 m Kiefernwald, Meybohm 11.5.2000" (cAss);

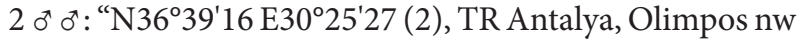
Ovacik 1255 m, Brachat \& Meybohm 12.4.2008" (cAss); $10^{\prime}$ : "TR. - Antalya, No. 23, W Kemer, road to Ovacik, Quercus litter, $325 \mathrm{~m}, 36^{\circ} 36^{\prime} 18 \mathrm{~N}, 30^{\circ} 28^{\prime} 38 \mathrm{E}, 2 . \mathrm{IV} .2002$, V. Assing" (cAss).

Etymology: The specific epithet (Latin adjective: doubled) alludes to the presence of two pairs of claw-shaped structures in the internal sac of the aedeagus.

Description: Body length 1.0-1.1 mm. Eye rudiments minute, composed of three or four weakly defined ommatidia without pigmentation. Other external and male secondary sexual characters as in the preceding species, except as follows:

$0^{*}$ : metaventrite depressed in the middle; aedeagus (Fig. 62-64) approximately $0.23 \mathrm{~mm}$ long; internal sac with two pairs of large and strongly curved claw-shaped structures, with an additional pair of weakly curved spines, and with a transverse apico-median structure; paramere apically extending beyond apex of median lobe, with short apical seta.

Intraspecific variation: The males from Termessos differ from those from other localities by slightly longer and more slender weakly curved structures (i.e., the most basal pair of internal structures). However, since slight variation was observed also in the shapes of the remaining structures and between specimens from all localities, and since no other evidence was found suggesting that these populations should represent distinct species, the observed differences are attributed to intraspecific variation.

Comparative notes: This species is reliably distinguished from the preceding representatives of the C. unguicum subgroup by the presence of three pairs of large sclerotized spines in the internal sac of the aedeagus. 
Distribution and natural history: The known distribution of C. geminum is confined to the west of Antalya province, Southwest Anatolia (Map 3). The specimens were sifted from litter in oak and pine forests and in a north slope with cedar, cypress, and oak shrubs at altitudes of 325-1255 m.

\section{Cephennium duplum spec. nov.}

urn:Isid:zoobank.org:act:B2B65A3E-757E-44EB-9F6F-C46D7523A3EB

(Figs 65-66, Map 3)

Type material: Holotype ơ: "N36²3' E02914', Türkei Umg. Fethiye, Kadyanda 850 m, Meybohm 28.4.2001 / Holotypus ơ Cephennium duplum sp. n., det. V. Assing 2020” (cAss). Paratypes: 1 o $^{\top}$ : “N36³3' E02907', T Umg. Fethiye, Ölüdeniz, 150 m, 27.4.2001, Meybohm/Brachat" (cAss); 1 ㅇ: "N36³3' E02907', Türkei Umg. Fethiye, Ölüdeniz, 150 m, Meybohm 27.4.2001" (cAss); 1 \% "N36³6' E02906', Türkei Umg. Fethiye, Fethiye, 360 m, Meybohm 27.4.2001” (cAss).

Etymology: The specific epithet (Latin adjective: doubled) alludes to the presence of two pairs of claw-shaped structures in the internal sac of the aedeagus.

Description: Body length $0.9-1.0 \mathrm{~mm}$. Eye rudiments minute, composed of three or four weakly defined ommatidia without pigmentation. Other external and male secondary sexual characters as in the preceding species.

$\sigma^{7}$ : aedeagus (Fig. 65-66) approximately $0.20 \mathrm{~mm}$ long; internal sac with two pairs of large and strongly curved claw-shaped structures, with an additional pair of weakly curved spines, and with a transverse apico-median structure; paramere apically extending beyond apex of median lobe, with short apical seta.

Intraspecific variation: The internal structures of the two examined males are not completely identical (Figs 65-66). However, the differences are only slight and the two localities are close, so that the differently shaped internal structures are interpreted as intraspecific variation.

Comparative notes: As can be inferred from the similar shapes and arrangement of the internal structures of the aedeagus, C. duplum is most closely allied to the geographically close C. geminum, from which it differs by slightly smaller body size and a smaller aedeagus with less massive and less strongly curved internal spines and with a differently shaped apical structure.

Distribution and natural history: The specimens were found in three localities near Fethiye, Muğla province, Southwest Anatolia (Map 3). The altitudes range from 150 to $850 \mathrm{~m}$.

\section{Unidentified and unnamed species}

The following material is represented exclusively by females, so that an adequate description is not possible. Based on external characters, all of them most likely belong to the C. corruptum group.

\section{Cephennium sp. 1}

Material examined: 1 \% : "N3943'29 E27ำ11'01 (13), TR Canakkale 14.4.2010, Kurucam Tepe $430 \mathrm{~m}$, leg. Brachat \& Meybohm" (cAss).

\section{Cephennium sp. 2}

Material examined: 1 ㅇ: "N41 ${ }^{\circ} 13^{\prime} 20$ E31 ${ }^{\circ} 53^{\prime} 6$ (26,2), TR Zonguldak 3.5.2014, Devrek $590 \mathrm{~m}$, leg. Brachat \& Meybohm" (cAss).

\section{Cephennium sp. 3}

Material examined: 1 ㅇ: "TR Umg. Osmaniye, Nur Dagl, Straße nach Zorkum, 550-900 m, N37 ${ }^{\circ} 1^{\prime}$ E36 $16^{\circ}$ / SüdTürkei, 25.4.2002, Brachat \& Meybohm” (cAss).

\section{Cephennium sp. 4}

Material examined: 1 \%: “N37³3'32 E036 35'20, TR Kahramanmaras, Baskonus Yaylasi 1450 m, 50 km von K. Maras (51) / Tannenwald, 5.5.2005 (51), leg. Brachat \& Meybohm” (cAss); 1 ㅇ: “N37³3'56 E036³3'38 (10), TR Kahramanmaras, Baskonus Yaylasi 1250 m, Brachat \& Meybohm 24.4.2007” (cAss).

\section{Appendix: A new Cephennium species from Bulgaria}

In the course of the present study, a male of a Cephennium species strongly resembling C.bodemeyeri and C. perispinctum from Bulgaria was examined. A careful study of the aedeagus revealed that it is conspecific with neither of them, but represents a new species.

\section{Cephennium liguliferum spec. nov. urn:Isid:zoobank.org:act:BE39D1DA-3677-435F-A8EB-D34BE361F9F5 (Figs 27-28, Map 1)}

Type material: Holotype $0^{\star}:$ "BG Strandzha Mts., Malko Tarnovo $300 \mathrm{~m}$, N41.98928 E27.52467, l. Bekchiev 18.4.2010 / Holotypus ơ Cephennium liguliferum sp. n., det. V. Assing 2020" (cAss). 
Etymology: The specific epithet (Latin, adjective: carrying a spoon) alludes to the spoon-shaped apex of the apical extension of the ventral process of the aedeagus in ventral view.

Description: Body length $1.3 \mathrm{~mm}$. External and male secondary sexual characters as in C.bodemeyeri and C. perispinctum:

$\sigma^{\top}$ : aedeagus (Figs 27-28) $0.55 \mathrm{~mm}$ long, slender; ventral process in ventral view with nearly parallel lateral margins, not constricted, with marked subapical angles, and apically with a long median extension, this extension apically somewhat spoon-shaped; internal sac with a pair of long and rather stout structures; paramere basally stout, smoothly tapering apicad, strongly bisinuate, and apically with long curved seta.

Comparative notes: Based on the similar external characters and particularly on the similar structure of the aedeagus, this species is undoubtedly closely allied to C. bodemeyeri and C.perispinctum. It is distinguished from both of them by the spoon-shaped apical extension of the ventral process and by much longer and more massive internal structures of the aedeagus.

Distribution: The type locality is situated in Strandzha Mountains, Southeast Bulgaria, not far from the border with the Turkish province Kirklareli (Map 1). The holotype was collected at an altitude of $300 \mathrm{~m}$.

\section{Acknowledgements}

We are indebted to Rostislav Bekchiev (Sofia), Volker Brachat (Geretsried), Michael Schülke (Berlin), and Paul Wunderle (Mönchengladbach) for the generous gift of Cephennium material, as well as to the late Claude Besuchet, his late wife Betty, and Volker Brachat for making numerous original aedeagus drawings and unpublished notes of Cephennium available to us.

\section{References}

Assing, V. 2019: Genus Cephennium Müller \& Kunze, 1822; pp. 266-273. - In: Assing, V.; Brachat, V. \& Меувонм, H. 2019: Monograph of the Staphylinidae of Crete (Greece). Part II. Descriptions of new species (Insecta: Coleoptera). - Contributions to Entomology 69 (2): 239-289.

Assing, V. \& Schülke, M. 2019: The Staphylinidae of Armenia and Nagorno-Karabakh (Coleoptera). Contributions to Entomology 69 (1): 91-173.

Jaloszyński, P. \& Stevanović, M. 2015: A new Cephennium of Kyrgyzstan, with notes on subgenera and distribution (Coleoptera, Staphylinidae, Scydmaeninae). - Zootaxa 3973 (2): 381-390.
JAŁoszyŃski, P. \& STRuyve, T. 2016: A new subterranean Iberian Cephennium with unusually modified metatrochanters (Coleoptera, Staphylinidae, Scydmaeninae). - Zootaxa 4189 (2): 291-300.

Мечвонм, H. 2016: Scydmaeninae; pp. 254-258. - In: Assing, V.: On the Staphylinidae of the Greek island Karpathos (Insecta: Coleoptera). - Linzer Biologische Beiträge 48 (1): 235-263.

Orousset, J. 2017a: Les espèces du genre Cephennium P. W. J. Müller \& Kunze, sous-genre Cephennium, de la faune de France (Coleoptera, Staphylinidae, Scydmaeninae). - Bulletin de la Société Entomologique de France 122 (3): 311-356.

Orousset, J. 2017b: Une espèce nouvelle du genre Cephennium P. W. J. Müller \& Kunze de la faune de France (Coleoptera Staphylinidae Scydmaeninae). L'Entomologiste 73 (5): 299-305.

Orousset, J. 2018: Le genre Cephennium P. W. J. MüLler \& Kunze, sous-genre Geodytes Saulcy. I. Espèces de France continentale, faune provençale exclue (Coleoptera, Staphylinidae, Scydmaeninae). - Bulletin de la Société Entomologique de France 123 (2): 213-236.

Orousset, J. 2019a: Le genre Cephennium Müller \& Kunze, sous-genre Geodytes SAulcy. II. Données complémentaires concernant les espèces de France (Coleoptera, Staphylinidae, Scydmaeninae). - Le Coléoptériste 22 (1): 13-20.

Orousset, J.2019b: Le genre Cephennium P. W. J. MüLleR \& Kunze, sous-genre Geodytes Saulcy. III. Taxons endemiques de Provence (Coleoptera, Staphylinidae, Scydmaeninae). - Bulletin de la Société Entomologique de France 124 (4): 363-400.

Reitter, E. 1882: Bestimmungs-Tabellen der europäischen Coleopteren. V. Paussidae, Clavigeridae, Pselaphidae und Scydmaenidae. - Verhandlungen der KaiserlichKöniglichen Zoologisch-Botanischen Gesellscahft in Wien 31 [1881]: 443-593.

Reitter, E. 1903: Neue, von Herrn Hauptmann E. von Bodemeyer im Jahre 1903 in Kleinasien gesammelte Coleopteren, vorzüglich Pselaphiden und Scydmaeniden. - Wiener Entomologische Zeitung 22: 221-224.

Schülke, M. \& SmetanA, A. 2015: Staphylinidae, pp. 304-1134. - In: LöBL, I. \& LöBL, D. (eds), Catalogue of Palaearctic Coleoptera. New, updated Edition. Volume 2. Hydrophiloidea - Staphylinoidea. Revised and updated edition. - Leiden: Brill: xxvi + 1702 pp.

Vít, S. \& Besuchet, C. 2004: Cephenniini; pp. 203-206. - In: Löbl, I. \& SMetanA, A. (eds), Catalogue of Palaearctic Coleoptera. Volume 2. Hydrophiloidea - Histeroidea - Staphylinoidea. - Apollo Books, Stenstrup: 942 pp. 